\title{
Globalization, history and international migration: a view from Latin America
}

Working Paper No. 37

\begin{abstract}
Andrés Solimano
Policy Integration Department

Word Commission on the Social Dimension of Globalization

International Labour Office

Geneva
\end{abstract}

July 2004

Working papers are preliminary documents circulated

to stimulate discussion and obtain comments 


\section{Copyright (C) International Labour Organization 2004}

Publications of the International Labour Office enjoy copyright under Protocol 2 of the Universal Copyright Convention. Nevertheless, short excerpts from them may be reproduced without authorization, on condition that the source is indicated. For rights of reproduction or translation, application should be made to the Publications Bureau (Rights and Permissions), International Labour Office, CH-1211 Geneva 22, Switzerland. The International Labour Office welcomes such applications.

Libraries, institutions and other users registered in the United Kingdom with the Copyright Licensing Agency, 90 Tottenham Court Road, London W1T 4LP [Fax: (+44) (0)20 7631 5500; email: cla@cla.co.uk], in the United States with the Copyright Clearance Center, 222 Rosewood Drive, Danvers, MA 01923 [Fax: (+1) (978) 750 4470; email: info@copyright.com] or in other countries with associated Reproduction Rights Organizations, may make photocopies in accordance with the licences issued to them for this purpose.

\section{ISBN 92-2-116318-0 (printed version)}

92-2-116319-9 (web version)

First published 2004

Cover:

The designations employed in ILO publications, which are in conformity with United Nations practice, and the presentation of material therein do not imply the expression of any opinion whatsoever on the part of the International Labour Office concerning the legal status of any country, area or territory or of its authorities, or concerning the delimitation of its frontiers.

The responsibility for opinions expressed in signed articles, studies and other contributions rests solely with their authors, and publication does not constitute an endorsement by the International Labour Office of the opinions expressed in them.

Reference to names of firms and commercial products and processes does not imply their endorsement by the International Labour Office, and any failure to mention a particular firm, commercial product or process is not a sign of disapproval.

ILO publications can be obtained through major booksellers or ILO local offices in many countries, or direct from ILO Publications, International Labour Office, CH-1211 Geneva 22, Switzerland. Catalogues or lists of new publications are available free of charge from the above address, or by email: pubvente@ilo.org

Visit our website: www.ilo.org/publns 


\section{Globalization, history and international migration: a view from Latin America}

\section{Contents}

Foreword

Preface

1. Introduction

2. International migration to and from Latin America:

A brief historical overview 2

First wave of globalization and the age of mass migration (circa 1870-1913)

War, instability, depression and de-globalization (1913-1945)

The post-1950 period: The second wave of globalization and constrained international labour markets

Intra-Latin American migration

Remittances

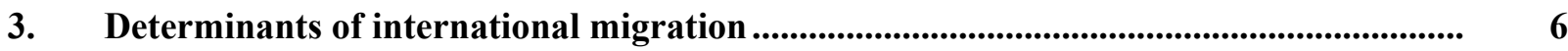

Economic determinants of international migration............................................. 6

Political regimes and international migration ............................................

4. From a net immigration to a net emigration country: Argentina in the 20th century .. 8

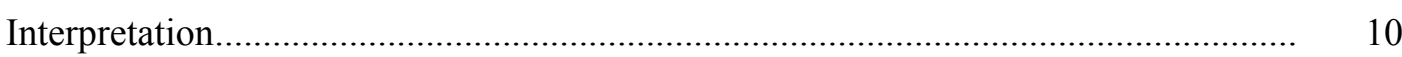

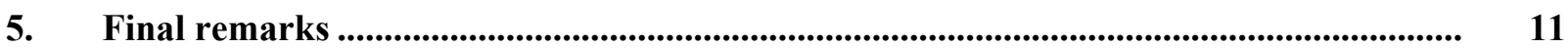

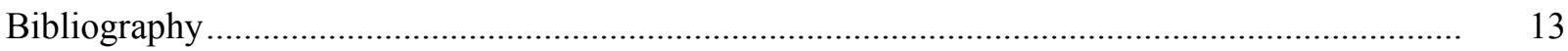

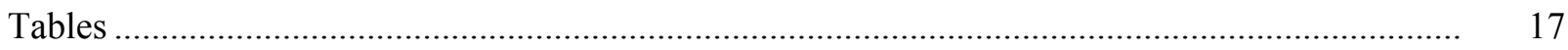




\title{
Foreword
}

In February 2002, the ILO established an independent World Commission on the Social Dimension of Globalization, co-chaired by President Tarja Halonen of Finland and President Benjamin Mkapa of Tanzania and comprising 26 eminent commissioners from a wide range of walks of life and different parts of the world, each serving in their individual capacity. Its broad goals were: to identify policies for globalization that reduce poverty, foster growth and development in open economies, and widen opportunities for decent work; to explore ways to make globalization inclusive, so that the process can be seen to be fair for all, both between and within countries; to promote a more focused international dialogue on the social dimension of globalization; to build consensus among key actors and stakeholders on appropriate policy responses; and to assist the international community forge greater policy coherence in order to advance both economic and social goals in the global economy.

The report of the World Commission, A fair globalization: Creating opportunities for all, was released on 24 February 2004. It is available on the Commission's website www.ilo.org/public/english/wcsdg/index.htm.

A secretariat was established by the ILO to support the Commission. Among other tasks, it compiled information and commissioned papers on different aspects of the social dimension of globalization. The aim was to provide the Commission with documentation and data on a wide range of options and opinions concerning subjects within its mandate, without committing the Commission or individual Commissioners to any particular position on the issues or policies concerned.

Material from this background work is being made available as working papers, as national and regional reports on meetings and dialogues, and in other forms. Responsibility for the content of these papers and publications rests fully with their authors and their publication does not constitute an endorsement by the World Commission or the ILO of the opinions expressed in them.

\author{
Gerry Rodgers \\ Director \\ Policy Integration Department
}




\title{
Preface
}

The Technical Secretariat to support the World Commission on the Social Dimension of Globalization first prepared a synthesis of ILO activities on the Social Dimension of Globalization (published as Working Paper No. 1 in this series). Documentation on the work and outcomes of other major commissions, an ideas bank, a database and knowledge networks of experts and social actors were subsequently developed. These networks have dealt with several topics, including: inclusion at the national level for the benefits of globalization to reach more people; local markets and policies; cross-border networks of production to promote decent work, growth and development; international migration as part of the Global Policy Agenda; international governance (including trade and finance); the relationship between culture and globalization; and values and goals in globalization. Gender and employment aspects were addressed throughout this work. The Reports on the Secretariat's Knowledge Network Meetings are available on the Commission's web site or in a special publication from the ILO (ISBN 92-2-115711-1).

During the course of these activities, a number of substantive background papers were prepared, which are now made available for wider circulation in the Policy Integration Department's Working Paper series (Nos. 16 to 38), as well as on the Commission's website.

In this paper André Solimano, currently a Senior Advisor to the UN Economic Commission for Latin America, with previous director positions in the World Bank and the Inter American Development Bank, shows that international migration in Latin America was largely unrestricted during the first wave of globalization (circa 1870-1913), in line with increasingly integrated capital and goods markets under the monetary arrangements of the gold standard. This migration came to an end during the de-globalization period from 1914 to the mid- to late $1940 \mathrm{~s}$. The second wave of globalization in the late $20^{\text {th }}$ century saw a substantial increase in the level of capital mobility and international trade. However, international labour markets have remained segmented, with international migration remaining constrained for unskilled labour and the poor. However, people with scarce skills and high educational levels have become more internationally mobile with the increasing globalization of capital and goods markets.

International migration patterns to and from Latin America have been driven mainly by the differences in per capita income between the region and the rest of the world. Intraregional migration also reflects disparities in income per capita within Latin America. South-North migration has been dominated by Mexico and other Central American and Caribbean countries, which have become the main source of migrants to the United States. Empirical analysis also shows the negative impact of authoritarian regimes on net immigration. For example, the military regimes in Argentina led to the substantial emigration of professionals, scientists and other educated people, thereby de-capitalizing the most highly qualified human resource base of the country.

\author{
Rolph van der Hoeven \\ Manager, Technical Secretariat \\ World Commission on the Social Dimension of Globalization
}

July 2004 
1. Introduction

International labour markets are an important part of the process of globalization and economic interdependence across countries and regions. Historically, the first wave of globalization during the period between 1870 and 1913 involved substantial international mobility of people, reflecting the openness to goods and capital under the policy regime of the gold standard and low tariffs. This process was interrupted during the de-globalization period between 1914 and 1945, which was characterized by war, high inflation in the 1920 s, economic depression in the 1930s and political instability. These events cut the economic links that had been developed in the world economy and inaugurated a long era of more restrictive migration policies. The second wave of globalization in the late $20^{\text {th }}$ century saw a substantial increase in the level of capital mobility and international trade. However, international labour markets have remained segmented, with international migration remaining constrained for unskilled labour and the poor. In contrast, we are living in a world of high international mobility for individuals with a high level of human and financial capital, such as information experts, executives and international investors. ${ }^{1}$

Patterns of international migration as they relate to Latin America are linked to the interaction between the changing cycles and policy regimes of the global economy and the economic performance of the region. Large Latin American economies, such as Argentina (and to some extent Brazil), received significant flows of migrants in the age of mass migration which characterized late $19^{\text {th }}$ and early $20^{\text {th }}$ century globalization. Foreign capital and labour moved in tandem to countries such as Argentina to capture the economic opportunities that were opening up there at the time. Subsequently, as economic development came to falter in Argentina and Latin America failed to develop to its full potential, international migration from Europe slowed down very significantly and virtually stopped in the late 1950s and early 1960s.

Intra-Latin American migration developed in response to significant differentials in per capita income between countries sharing common borders. At the same time, Latin America became the main source region (Mexico being the main sending nation) of emigrants heading to the United States, a trend that accelerated in the 1980s and 1990s.

This paper investigates the interaction between globalization regimes, income differentials and international migration, with emphasis on the Latin American experience. The second section provides an overview of the different phases of globalization and de-globalization in the global economy and the patterns of international migration to and from Latin America over the past 130 years or so. The third section examines the case of Argentina, historically the main receptor of migrants in Latin America, and which in the $20^{\text {th }}$ century turned into a country of net emigration due to development failures, compounded by cycles of authoritarianism and political instability. The final section offers some conclusions.

\footnotetext{
1 For an analysis of the migration of human capital, see Solimano (2002a), Carrington and Detraigiache (1998) and Haque and Kim (1994). An early treatment of the subject is found in Adams (1968).
} 


\section{International migration to and from Latin America: A brief historical overview}

The main events in the global economy that have affected migration flows in significant ways at the global level, and in relation to Latin America in particular, are the two waves of globalization in the late $19^{\text {th }}$ and late $20^{\text {th }}$ centuries, as well as the de-globalization period of 1913-1945. This section assesses and interprets these trends.

\section{First wave of globalization and the age of mass migration (circa 1870-1913)}

The period of free trade, free capital mobility and the gold standard ${ }^{2}$ from around 1870 to 1913 has been described by economic historians as the "first wave of globalization". This period was also accompanied by major flows of international migration, known as the "age of mass migration" (see Hatton and Williamson, 1998). It is estimated that during this period around 60 million people migrated from resource-scarce labour-abundant Europe to the resource-abundant labour-scarce countries of the "New World", including Argentina, Australia, Brazil, Canada, New Zealand and the United States. Migrants came from both "core Europe" (France, Germany, United Kingdom) and "peripheral Europe" (the Scandinavian countries, Spain, Italy and Portugal, Poland, Russia, Romania and the former nations of the Austro-Hungarian Empire). In Latin America, the main destination country for migrants from Europe was Argentina, which received almost 7 million immigrants (of whom some 4 million subsequently returned to Europe). Other countries which received a relatively large number of European migrants were Chile, Cuba, Mexico and Uruguay.

Immigration policies in the countries of the New World during the first wave of globalization were, on the whole, liberal. ${ }^{3}$ Several New World countries, such as Argentina, set up immigration agencies in European countries to attract and facilitate immigration flows with a view to increasing labour supply and supporting rapid economic expansion. However, these policies became gradually more restrictive, particularly in the 1910s and 1920s. Ethnic discrimination against migrants from Asia, and particularly from China, was common in several receiving countries.

As shown in Table 1, per capita income differentials between "peripheral" Europe and the United States, Canada, Australia and other countries of the New World during the period 1870-1913 were significantly in favour of the countries of the New World, thereby encouraging widespread transatlantic migration. Argentina had a per capita income that was around 30 per cent higher than Spain and Italy in 1913. These income gaps created strong economic incentives for international migration to Argentina. Uruguay also had higher per capita income than Spain and Italy in 1913, while Chile was barely at the same level as those European nations.

\footnotetext{
${ }^{2}$ See Eichengreen (1996) for an analysis of the gold standard in this and subsequent periods.

3 The main reference on immigration policies in New World countries during the first wave of globalization is Timmer and Williamson (1996). More direct sources are Holloway (1997) for Brazil and Solberg (1970) for Argentina and Chile.
} 


\section{War, instability, depression and \\ de-globalization \\ (1913-1945)}

The outbreak of the First World War interrupted the process of growing economic interdependence and labour market integration across countries which characterized the first wave of globalization. The year 1914 inaugurated nearly 30 years of economic instability and political turbulence, characterized by the First World War, high inflation in Europe in the 1920s, economic depression in the 1930s and the Second World War in the first half of the 1940s. All this turbulence led to increasingly restrictive policies on international migration in some countries, such as the United States, which enacted immigration quotas in 1921 and 1924, reducing the flow of immigrants from Europe. Migrants then switched to Brazil and Argentina. The latter received around 3 million immigrants from Europe in the 1920s, although as many as 2 million returned (Chiswick and Hatton, 2002). At the same time, restrictions on emigration were enacted in the Soviet Union, thus reducing the Russian share of global migration flows to the Americas.

\section{The post-1950 period: The second wave of globalization and constrained international labour markets}

The end of the Second World War, the economic reconstruction of Europe and the rebuilding of trade and investment relations between nations in the second half of the 1940s and early 1950s gave rise to a new period of economic prosperity in the global economy. The prevailing policy regime was a system of fixed exchange rates, controlled international capital markets and constrained international migration. This cycle of prosperity and stability lasted until the early 1970s, when industrial countries were faced with the combination of oil price shocks and the collapse of the Bretton Woods parities. These two shocks led to a new period of adjustment in the global economy, along with other structural transformations. Economic internationalization received renewed impetus with the emergence of an active international capital market in the 1970s, which gained full force in the 1990s. However, the demise of Communism and growing liberalization reinforced the momentum of the "second wave of globalization".

The increasing global integration of goods and capital markets during the second wave of globalization has not, however, been followed by an equal degree of integration of international labour markets, ${ }^{4}$ which operate under a more constrained immigration policy framework than that existing up to 1913. From a Latin American perspective, immigration flows to Argentina (the main receiving country for foreign migrants) resumed in the mid1940s following the Second World War, and lasted until the mid- to late 1950s, when Europe once again started to grow on a sustained basis and Argentine's economic dynamism began to falter, reducing employment and business opportunities for both migrants and nationals. In 1950, the per capita income of Argentina, Uruguay and Venezuela was still higher than that of Italy, Spain and other "peripheral" European countries, although the differential was steadily and persistently shrinking. By the 1970s, there had been a reversal in the per capita income gap between Italy and Spain, on the one hand, and Argentina and Venezuela, on the other. As will be shown below, when analysing the case of Argentina in greater detail, the main economic incentives for emigration from Europe to Argentina virtually disappeared in the 1970s. Indeed, reverse migration from Argentina to Italy and Spain has become the norm since the 1970s (Solimano, 2002b).

\footnotetext{
${ }^{4}$ See Abella (1997), Stalker (2000) and Solimano (2001).
} 
The configuration of economic incentives for international migration in relation to Latin America during the course of the $20^{\text {th }}$ century was such that inflows from Europe (until the 1950s) coexisted with outflows (emigration) from various Latin America countries to the United States, Canada and other developed nations. An increase in international migration (from the world over) to the United States occurred in the 1980s and 1990s (see Table 2). There were about 1 million migrants to the United States during the decade of the 1940s and 2.5 million migrants in the $1950 \mathrm{~s}$, rising to nearly 7.5 million migrants per decade in the $1980 \mathrm{~s}$ and $1990 \mathrm{~s}$. It is interesting to note that although, during the $19^{\text {th }}$ century, most of the migrants to the United States were Europeans (around 88 per cent of the total migration to the United States during the period 1820-1920), this percentage declined to around 14 per cent during the period 1971-1998. During this latter period, the main source of immigration to the United States was from Latin America (46 per cent of the total), followed by Asia (34 per cent). In terms of individual countries, for a very long period of 179 years (1820-1998), as shown in Table 2, Mexico, Cuba and the Dominican Republic were the main Latin American source countries of immigrants to the United States. The main Asian sending countries were the Philippines, China, Republic of Korea and India, and the main European sending countries were Germany, Italy, United Kingdom and Ireland. ${ }^{5}$

\section{Intra-Latin American migration}

The importance of international differences in per capita income and living standards, in the context of a specific set of immigration policies, have been singled out in driving international migration flows. Table 3 shows significant differences in per capita GDP between Latin American countries during the period 1950-2000. For example, the per capita income of Argentina was, on average, over twice as high as that of Bolivia and Paraguay. As a consequence of these income gaps, Paraguay and Bolivia (in addition to Chile) became the two main source countries of migrants coming to Argentina (see Table 4). Per capita income in Chile is on average 65 per cent higher than that of Peru (and 80 per cent higher than that of Ecuador), with the gap widening in the 1990s, mainly because of the rapid growth of the Chilean economy during most of that decade. Large income per capita differentials may be observed between Venezuela and Colombia, although the gap has declined since the 1980s with the sharp worsening of Venezuela's economic performance over the past two decades. Significant income per capita differentials also exist between Costa Rica and Nicaragua, which have widened further since the 1980s due to the collapse of the Nicaraguan economy during its internal war in the 1980s and its weak performance subsequently. The gap between the Dominican Republic and Haiti started exploding during the 1980s and throughout the 1990s. The important point here is that divergent economic performance between Latin American countries, particularly between countries sharing common borders, appears to have led to significant migration flows between them. Table 5 shows, for various census years, the stocks of foreign nationals born within and outside the region and residing in other Latin American countries. The Table shows that Argentina has been the main recipient of people born in other Latin American countries (both in absolute numbers and as a share of its total population), although this is a declining trend. Indeed, the absolute number of foreign nationals living in Argentina has declined steadily from around 2.5 million in 1960

\footnotetext{
${ }^{5}$ Immigration flows represented, on average, around 7 per cent of the total population of the United States during the period 1871-1920; this percentage later declined to 2.5 percent in the last third of the $20^{\text {th }}$ century. On the other hand, there was an important increase in estimated illegal migration to the United States during the 1990s, from 3.3 million a year in 1992 to 5 million in 1996. In recent decades, Latin American countries have been the principal source of illegal immigrants to the United States, with the largest contingents coming from Mexico. Other important sending countries for illegal immigrants are El Salvador, Guatemala, Haiti, Honduras, Canada and the Philippines.
} 
(12.7 per cent of the total population) to around 1.6 million in 1991 ( 4.9 per cent of the total population). ${ }^{6}$ Another country in which the population of foreign nationals is significant is Venezuela, where their numbers rose from nearly 600,000 in 1970 to over one million in 1990. The other Latin American countries covered by Table 5 have a relatively low percentage of recorded foreign nationals living in their territories. It will nevertheless be interesting to know more about the evolution of these trends in the 1990s as more recent census figures become available.

\section{Remittances}

The counterpart of the physical movement of people abroad (emigration) is the remittance of income from labour or profits back home. This underlines the fact that net emigration is not per se a pure cost for the sending country. The accrual of remittances is a benefit of migration that has to be weighed against its costs. The quantitative significance of remittances for Latin America is high. It has been estimated that total remittances for the 14 Latin American countries representing over 75 per cent of regional GDP were nearly US\$23 billion in 2001 (Orozco, 2001). To put this figure in perspective, it should be borne in mind that total capital inflows into Latin America in 2001 amounted to nearly US\$70 billion and official grants to the region to nearly US\$3 billion (ECLAC, 2002). The average proportion of GDP accounted for by remittances in the 14 Latin American countries was 8.5 per cent, although with wide variations between countries. Remittances represent 24.5 per cent of GDP in Haiti, 17 per cent in El Salvador, 15 per cent in Jamaica and 9 per cent in Ecuador. In contrast, remittances account for less than 3 per cent of GDP in Peru, Colombia, Mexico, Brazil and Colombia. As a proportion of total exports, remittances represent over 150 per cent in Haiti, 80 per cent in Nicaragua, 60 per cent in El Salvador and 20 per cent in Ecuador. It is worth noting that figures for remittances may be somewhat understated, as they often transit through unrecorded informal channels (such as personal transportation by friends or relatives and other unrecorded transactions). Remittances are bound to have a significant macroeconomic impact in some countries in complementing domestic savings and investment.

\footnotetext{
${ }^{6}$ The last year for published census figures is 1991 .
} 


\section{Determinants of international migration}

Following this review of the main trends of global and regional migration in relation to Latin America over the varous historical periods, it is now necessary to turn to the main economic determinants of migration and related topics.

\section{Economic determinants of international migration}

The economics of migration focus on the expectation of a higher income abroad as a chief cause of decisions to emigrate. There are also other variables that exert an important influence on decisions to migrate, including non-economic reasons, such as war, ethnic discrimination and political persecution at home. The choice of country of destination is also often influenced by the existence of a network of family and friends who have migrated previously to a specific country. ${ }^{7}$ More systematically, the magnitude and direction of international migration flows are often influenced by the following factors, some of which are of a long-term nature, while others are more cyclical:

(a) Per capita income or real wage differentials between sending and receiving countries for a given skill level: net immigration flows (immigration minus emigration) are positively correlated to the ratio between the real per capita income (or real wage) in the destination country and that of the recipient country. ${ }^{8}$ Taking into account uncertainty and a long-term horizon in reaching the decision to emigrate, what is more relevant is the expected wage in the place of destination compared with that of the source country. Moreover, in a dynamic perspective, the current value of expected relative wage streams would be the relevant variable.

(b) The state of the business cycle and economic prospects in both sending and receiving countries. Rapid economic growth and labour shortages in receiving countries tend to increase the probability of immigrants finding a job. In contrast, in periods of sluggish growth and higher unemployment, this probability is lower. While the decision to emigrate depends largely on real income differentials between countries, the timing of migration seems to be correlated with the state of the business cycle in both sending and receiving countries.

(c) Network effects. Empirical analysis of migration flows (Hatton and Williamson, 1998; Borjas, 2001) shows that migrants tend to attach a high value to the existence of friends and relatives in their selection of the country of destination. Indeed, family, friends and ethnic/national networks constitute an important support factor for migrants. They can help them obtain information about jobs and other relevant national characteristics of the host nation, thereby assisting in the adjustment of individuals and families following migration.

\footnotetext{
${ }^{7}$ Migration equations usually include as determinants the following variables: the ratio between the real wage (or real per capita income) in the home country relative to that of the country of destination; a lagged migration variable capturing persistent effects and the effects of friends and relatives (social network considerations); a two-decade lagged demographic variable representing population growth; and a variable denoting the degree of industrialization of the home country. See O'Rourke and Williamson (1999).

${ }^{8}$ See Hatton and Williamson (1998: Chapters 3 and 4) for a detailed discussion of the impact of wage gaps on emigration flows from Europe to New World countries in the late $19^{\text {th }}$ and early $20^{\text {th }}$ centuries.
} 
(d) Immigration policies. Policies in host countries that are unfavourable to immigration deter migrants, although not completely, as there still remains the possibility of illegal migration to some countries (for an interesting analysis of the political economy of migration policies in receiving countries, see Chiswick and Hatton, 2002).

(e) Costs of migrating. Emigration entails several costs, including travel costs, such as air tickets and shipping costs, and living expenses in the host country, as well as the cost of searching for a job. Unskilled and poor migrants are often affected by these costs, which may in practice be an important inhibiting factor on the international migration of the poor.

(f) Cultural differences between countries. Features such as language, traditions and family relationships affect migration patterns. As these cultural traits often differ between the host country and the sending nation, they tend to act as dampening factors upon international migration.

(g) Geographical distance and proximity. In general, migration to border countries (or countries of proximity) tends to be more common than to countries located far away. Geography therefore matters in relation to the direction and size of migration flows.

\section{Political regimes and international migration}

Outflows and inflows of migrants do not only depend on the economic conditions in sending and receiving countries. The political regimes prevailing in host and source countries (democracy or authoritarianism) also matter in the decision to emigrate. Individuals prefer to live in countries in which civic freedoms and individual rights (such as freedom of speech and association, access to a fair trial, religious freedom and the right to elect public authorities) are respected and economic rights (property rights, contract enforcement) are protected. This tends to occur more often in democracies than in dictatorships, which curtail individual rights and engage in repressive activities. ${ }^{9}$ Albert Hirschman, in his classic book Exit, voice and loyalty (1972), draws a distinction between purely economic choices and collective action which is useful in understanding the economic and political causes of migration decisions. While the decision to leave a country is often an economic choice, voice belongs to the realm of collective or political action. This framework suggests that individuals who are dissatisfied or discontent with current political and economic conditions in their home countries, where "voice" has become an ineffective expedient for change, may choose to leave their countries (that is to emigrate). Thus (voluntary) migration (which differs from the situation of refugees and asylumseekers, which are instances of forced migration) as a decision is also affected by political conditions that are considered to be inadequate by nationals and foreign residents. This suggests a direct relationship between the emigration of nationals (or the repatriation of foreigners) and the existence of authoritarian regimes which suppress political rights and civil liberties. There are several examples of this in Latin America: the onset of military regimes in Argentina in the 1960s and 1970s, which curtailed civil liberties and intervened in universities (suppressing academic freedoms), was followed by a massive outflow of professionals and scientists, with serious consequences for the country in terms of the brain drain. A similar situation occurred in Brazil in the 1960s and 1970s, and subsequently in Chile in the 1970s and 1980s. In these cases, emigration (very often of individuals with a high stock of human capital) becomes an individual response to non-democratic political regimes which fail to respect civic rights.

\footnotetext{
${ }^{9}$ See Olson (2000) for an insightful analysis of the economic consequences of democracies and autocracies.
} 


\section{From a net immigration to a net emigration country: Argentina in the 20th century ${ }^{10}$}

During the course of the $20^{\text {th }}$ century, Argentina declined from being among the six most developed economies in the world in the late 1920s to an economy in the middle income range of the developing world in the last quarter of the century. As a consequence, it switched from being a country of net immigration from 1870 to the 1950 s to a net emigration country, often of highly educated citizens, in the last decades of the $20^{\text {th }}$ century.

The process of economic development in Argentina went through different phases and cycles, which over time started to diverge from the best performers in the world economy. The period beween 1870 and 1914, labelled by economic historians as Argentina's belle époque, ${ }^{11}$ was characterized by rapid economic growth, large inflows of foreign capital and, as noted above, massive immigration from Europe, mainly from Italy and Spain, two countries which accounted for nearly 80 per cent of total immigration into the country (Bunge and Garcia-Mata, 1969). Argentina's belle époque coincided with the period of the "first wave of globalization", ${ }^{12}$ when it was one of the most prosperous economies of the period. Indeed, between 1870 and 1914, the Argentine economy grew at an annual rate of close to 6 per cent a year, one of the highest in the world economy at the time, and the level of income per capita in Argentina was between 33 and 38 per cent higher than the per capita income of Spain and Italy, respectively (see Table 7).

Migration policy in Argentina was to seek actively to recruit migrants abroad. By the mid$19^{\text {th }}$ century, Argentina had opened recruitment offices in Italy and Spain and granted land to facilitate the settlement of immigrants. The Government also financed the costs of moving and provided housing for immigrants. These measures helped to attract massive international migration to Argentina during the period 1870-1914.

During this period, the average annual net immigration into Argentina amounted to nearly 57,000 persons a year over a 45-year period (the rate of net migration per 1,000 inhabitants was over 15 per cent; see Table 7). Net immigration fell sharply in the early interwar years (1914-1929) to around 40,000 net immigrants a year (nearly half the number during the period 1900-1914). The early interwar years were highly disruptive for the world economy and Argentina was not immune to the international situation. Its access to external financing was restricted by the continued disorganization of world capital markets and suffered from the disruption of European export markets. ${ }^{13}$ Migration flows reflected the combination of diminished economic opportunities in Spain and Italy, in contrast with the abundance of land, scarcity of labour and dynamic export industry in grain and meat (mainly to the British market) in Argentina. Foreign capital provided resources to build (and upgrade) infrastructure, such as railways, ports and roads, with foreign immigration providing the labour and entrepreneurial capacities required to seize the available opportunities.

\footnotetext{
${ }^{10}$ See Diaz-Alejandro (1970), Bunge and Garcia-Mata (1969), Cortes Conde (1994) and Taylor (1994a).

11 See Diaz-Alejandro (1970), Bunge and Garcia-Mata (1969), Cortes Conde (1994) and Taylor (1994a).

${ }^{12}$ See Della Paolera (1994).

${ }^{13}$ See Della Paolera and Taylor (1998).
} 
The 1930s were bad for the Argentine economy: GDP growth declined to an annual rate of 1.5 per cent between 1930 and $1940 .{ }^{14}$ In the same way as other Latin American economies at the time, Argentina adopted an inward-looking development strategy in the early 1930s and raised tariffs on imports of intermediate and capital goods. ${ }^{15}$ The economic decline in Argentine sharply reduced net immigration flows into the country, which fell to nearly 22,000 immigrants a year between 1930 and 1940. After the Second World War, there was a resumption of European migration to Argentina until the mid-1950s. The human and economic devastation brought about by the Second World War compelled Europeans to leave their home countries and Argentina was a natural destination in view of the earlier ties and knowledge of the country acquired during the major migration waves of the late $19^{\text {th }}$ and early $20^{\text {th }}$ centuries. However, the combination of rapid economic recovery in Europe in the late 1940s and 1950s and sluggish economic performance in Argentina in the 1940s and 1950s steadily reduced incentives for migration to the country, as gaps in income per capita closed between Argentina and European countries. Immigration from Europe to Argentina declined sharply in the 1960s (see Table 6) and almost ceased in the 1970s and 1980s. ${ }^{16}$

Coinciding with the decline in immigration from Europe since in the 1950s, there has been an increase in international migration to Argentina from neighbouring countries, rather than from overseas. As noted above, there were considerable flows of migrants, mainly consisting of rural workers and unskilled urban labour from Bolivia, Chile and Paraguay. ${ }^{17}$ In addition to this change in the countries of origin of migrants coming to Argentina, there has also been an important phenomenon since the 1930s of internal migration from rural areas to the cities in Argentina associated with import-substitution industrialization, the growth of government and deepening urbanization. Immigrants from neighbouring countries therefore tended to take jobs in rural areas that were no longer wanted by rural Argentinean workers, who had migrated to the cities. Another important trend in the $1950 \mathrm{~s}, 1960 \mathrm{~s}$ and $1970 \mathrm{~s}$ was the emigration of Argentine nationals, particularly professionals, highly skilled workers, scientists and intellectuals. ${ }^{18}$ An important reason for the emigration of scientists and highly qualified persons during this period, in addition to the disincentive of economic decline, lay in the policies of both the Peron administration in the 1950s, which excluded non-peronist intellectuals and professionals, and the open hostility of the military regimes of the $1960 \mathrm{~s}$ to dissidence in the universities. This situation reached a dramatic peak in 1967 under the government of General Juan Carlos Onganía. A total of 1,305 faculty members were expelled from the University of Buenos Aires alone as a result of the intervention of the Onganía government (Lattes, Oteíza and Gracierena, 1986). In addition to directly expelling professors from universities, a "brain drain" dynamic subsequently developed as intellectuals started to leave Argentina because of the risk of being dismissed (and possibly imprisoned), combined with the adverse

${ }^{14}$ See Della Paolera and Taylor (1998) and Diaz-Alejandro (1970) for an analysis of the impact of the external shocks of the 1930 s and Argentina's policy response.

15 Diaz-Alejandro (1970) and Taylor (1994a) have shown that the import substitution policies adopted in the 1930s in Argentina contributed significantly to the increase in the relative price of capital goods on the domestic market, thereby discouraging capital formation and growth.

${ }^{16}$ As a consequence of this reversal, Argentina's GDP per capita was on average, during the period 1975-2000, below that of Spain (72 per cent) and Italy (55 per cent) (see Table 7).

17 Paraguayans and Bolivians mostly migrated to the northern areas of Argentina. However, migrants from Chile often went to work on southern farms and the oil fields of Patagonia.

18 See Lattes, Oteíza and Graciarena (1986) for statistics of the emigration of medical doctors, engineers, scientists and "technicians" from Argentina to the United States between 1950 and 1970. 
incentive of sustained budget cuts in the universities, which retarded the development of research and teaching in the country. ${ }^{19}$ After an interlude of democratic governments in the early 1970s, the situation worsened once again following the military coup in 1976, when the massive repression of scientists, professionals and students was part of an overall strategy to weaken any potential opposition to the military regimes which were endeavouring to consolidate in the country at the time. ${ }^{20}$

\section{Interpretation}

In the last quarter of the $20^{\text {th }}$ century, the combination of sluggish economic performance and political cycles of authoritarianism turned Argentina into a country of net emigration. Volatile growth and macroeconomic instability since the 1950s (although partially reversed for a short period in the 1990s) clearly reversed the strong economic incentives for immigration that had existed in Argentina in the late $19^{\text {th }}$ and early $20^{\text {th }}$ centuries. Moreover, populist-nationalist governments and repressive military regimes also acted as a disincentive to immigration from Europe. ${ }^{21}$ Worse still, these regimes forced the best qualified, and therefore the most mobile citizens, to emigrate in significant numbers at different times during the second half of the $20^{\text {th }}$ century. ${ }^{22}$

An econometric estimate of net migration in Argentina during the $20^{\text {th }}$ century, including the various sub-periods (see Tables 8-11), is provided in Solimano (2002b). The main results of this study can be summarized as follows:

(a) There is a positive and significant effect on net migration flows (migration minus emigration) to and from Argentina of the gap between the per capita income in Argentina (the recipient country) and that of sending countries (chiefly European until the mid-1950s, and thereafter Bolivia, Chile and Paraguay). The results show that the gap in income per capita between Argentina and sending countries is a robust determinant of net immigration throughout the various sub-periods of the $20^{\text {th }}$ century. This also confirms the important role of relative income differentials in driving international migration, as indicated in Section 3.

(b) The econometric results also show a statistically significant negative effect of authoritarian regimes on immigration flows to Argentina (and, conversely, a positive effect on emigration flows from Argentina), confirming the importance of political regimes on decisions to migrate (based on the suppressing effect of authoritarian regimes on civic liberties, academic freedoms and human rights). However, this effect seems to be more important for the emigration of skilled workers and those with a

${ }^{19}$ The case of Cesar Milstein is illustrative. This outstanding scientist emigrated from Argentina and went to work in the University of Cambridge, where he received a Nobel Prize a few years later.

${ }^{20}$ A practical complication in understanding the effect of this period on migration flows lies in the fact that during the period 1976-1981 the military regimes largely stopped recording outflows of Argentine nationals.

${ }^{21}$ These political characteristics of Argentina apparently did not deter immigration from Bolivia or Paraguay, which also had their share of authoritarian regimes.

${ }^{22}$ Argentina experienced considerable political instability and frequent changes between democratic and authoritarian regimes from the early 1930s and throughout the early 1980s. The cycle of replacing democratically elected governments with authoritarian regimes started with Jose Uriburu in 1930, following the last government of Hipolito Irigoyen, and ended with the military regime of General Galtieri in 1983. The democratic election of President Raul Alfonsín then inaugurated an almost 20-year cycle of uninterrupted democracy in Argentina. 
high level of human capital, who are more mobile and can afford to migrate to other countries.

\section{Final remarks}

This paper shows that international migration was largely unrestricted during the first wave of globalization (circa 1870-1913), in line with increasingly integrated capital and goods markets under the monetary arrangements of the gold standard. This reality came to an end during the de-globalization period from 1914 to the mid- to late 1940s, which comprised two World Wars, macroeconomic instability in the 1920s, economic depression in the 1930s and recurrent political turbulence. This created a climate that was conducive to a more restricted regime of international migration.

International labour markets have remained constrained, in the sense of the restrictive immigration policies adopted in advanced economies, particularly for unskilled labour, during the second wave of globalization which started in the 1970s. However, people with scarce skills and high educational levels (professionals, information experts, international investors) have become more internationally mobile with the increasing globalization of capital and goods markets.

International migration patterns to and from Latin America have been driven mainly by the differences in per capita income between the region and the rest of the world. Intraregional migration also reflects disparities in income per capita within Latin America. South-North migration has been dominated by Mexico and other Central American and Caribbean countries, which have become the main source of migrants to the United States. Historically, Argentina was a very significant recipient country of labour migrants from Europe during the age of mass migration in the late $19^{\text {th }}$ and early $20^{\text {th }}$ centuries. However, as economic growth in Argentina slowed down and became more unstable from the 1930s onwards, opportunities for migrants from Europe declined and this source of migration virtually disappeared in the late 1950s, to be replaced by migration from lower income per capita countries, such as Bolivia and Paraguay. In addition, the second half of the 20th century saw Argentina become a net emigration country (mainly of professionals and highly qualified people), coinciding with the persistent economic decline and instability of the country, compounded by the political authoritarianism of the 1960s and 1970s. A time series econometric analysis of Argentina shows the importance for net immigration rates of income gaps between Argentina and sending nations. This finding is robust for the various sub-periods of the $20^{\text {th }}$ century. Empirical analysis also shows the negative impact of authoritarian regimes on net immigration. Indeed, the military regimes in Argentina led to the substantial emigration of professionals, scientists and other educated people, thereby de-capitalizing the most highly qualified human resource base of the country. 


\section{Bibliography}

Abella, M. 1997. Sending workers abroad: A manual for low- and middle-income countries. Geneva, ILO.

Adams, W. (ed.) 1968. The brain drain. New York and London, Macmillan.

Borjas, G.J. 2001 Heaven's door: Immigration policy and the American economy. Princeton University Press.

Bunge, A. and Garcia-Mata, C. 1969. "Argentina", in Willcox, W., International migrations (Vol.2): Interpretations. New York, National Bureau of Economic Research.

Carrington, W. and Detraigiache, E. 1998. How big is the brain drain? Working Paper 98/102. IMF.

Chiswick, B. and Hatton, T. 2002. International migration and the integration of labor markets. IZA Discussion Paper No. 559. Bonn, Institute for the Study of Labour.

Cortes Conde, R. 1979. El progreso argentino. Buenos Aires, Editorial Sudamericana.

----. 1994. Estimaciones del producto bruto interno de Argentina, 1875-1935. Working Paper No. 3. University of San Andrés.

Della Paolera, G. 1994. "Experimentos monetarios y bancarios en Argentina: 1861-1930", in Revista de Historia Económica. 3.

Della Paollera and Taylor A. 1997. Finance and development in an emerging market: Argentina and the interwar period. NBER Working Paper No. 6236. Cambridge MA.

----. 1999. "Economic recovery from the Argentine great depression: Institutions, expectations and the change of macroeconomic regime", in Journal of Economic History. 59(3): 567-599.

Diaz-Alejandro, C. F. 1970. Essays on the economic history of the Argentine Republic. New Haven, Yale University Press.

Di Tella, G. and Zymelman M. 1973. Los ciclos económicos argentinos. Buenos Aires, Editorial Piadós.

ECLAC. 2002. Globalization and development. Santiago de Chile.

Eichengreen, B. 1996. Globalizing capital: A history of the international monetary system. Princeton University Press.

Ferenczi, I. and Wilcox, W. 1929. International migration (Vol. I): Statistics. National Bureau of Economic Research.

Haque, N. and. Kim, S. 1994. Human capital flight: Impact of migration on income and growth. IMF Working Paper 94/155.

Hatton, T.J. and Williamson, J.G. 1998. The age of mass migration. Causes and economic impact. Oxford University Press.

Hirschman, A. 1972. Exit, voice and loyalty: Responses to decline in firms, organizations and States. Harvard University Press.

----. 1995. "Exit, voice and the fate of the German Democratic Republic", Chapter 1 in Hirschman, A., A propensity to self-subversion. Harvard University Press.

Holloway, T.H. 1977. "Immigration and abolition: The transition from slave to free labor in the Sao Paulo coffee zone", in Alden, D. and Dean W. (eds), Essays concerning the socioeconomic history of Brazil and Portuguese India. Gainsville, University Presses of Florida. 
ILO. 2002. ILO activities on the social dimensions of globalization: Synthesis report. Geneva.

Lattes, A.E., Oteíza, E. and Graciarena, J. 1986. Dinámica migratoria argentina (19551984): Democratización y retorno de expatriados. UNRISD.

Lindert, P. and Williamson, J. 2001. Does globalization make the world more unequal? Paper presented at the NBER Conference on Globalization in Historical Perspective, Santa Barbara.

Maddison, A. 1995. Monitoring the world economy, 1820-1992. Paris, OECD.

OECD. 2001. International mobility of the highly skilled. Proceedings of the seminar on this subject held in Paris (June).

Olson, M. 2000. Power and prosperity: Outgrowing communist and capitalist dictatorships. New York, Basic Books.

Orozco, M. 2001. Globalization and migration: The impact of family remittances in Latin America. Inter-American Dialogue (mimeo).

O'Rourke, K. and Williamson, J. 1999. Globalization and history: The evolution of a nineteenth-century Atlantic economy. Cambridge MA, MIT Press.

Oteíza, E. 1997. "Emigración de profesionales, técnicos y obreros calificados argentinos a los Estados Unidos: Análisis de las fluctuaciones, junio de 1950 a junio de 1970", in Desarrollo Económico. 39-40.

Pellegrino, A. and Martínez Pizarro, J. 2001. Una aproximación al diseño de políticas sobre la migración internacional calificada en América Latina. Serie Población y Desarrollo. Santiago de Chile, ECLAC.

Solberg, C.E. 1970. Immigration and nationalism: Argentina and Chile, 1890-1914. Austin and London, University of Texas Press.

----. 1978. "Mass migrations in Argentina, 1870-1970", in McNeill, W.H. and Adams, R.S (eds.), Human migration: Patterns and policies. Bloomington, Indiana University Press.

Solimano, A. 2001. International migration and the global economic order: An overview. Working Paper - International Economics, Trade, Capital Flows, No. 2720. Washington DC, World Bank.

----. 2002a. Globalizing talent and human capital: Implications for developing countries. Macroeconomics of Development Series, No 15. Santiago de Chile, ECLAC.

----. 2002b. Development cycles, political regimes and international migration: Argentina in the $20^{\text {th }}$ century. Paper presented at the WIDER Conference "Poverty, International Migration and Asylum", September, Helsinki.

Solimano, A., Aninat, E. and Birdsall, N. (eds.). 2000. Distributive justice and economic development: the case of Chile and developing countries. University of Michigan Press.

Stalker, P. 2000. Workers without frontiers: The impact of globalization on international migration. Boulder, Lynne Rienner, and Geneva, ILO.

Taylor, A. 1994a. Three phases of Argentine economic growth. NBER Working Paper No. H0060. Cambridge MA.

----. 1994b. "Mass migration to distant southern shores: Argentina and Australia, 1870-1939", in Hatton, T. and Williamson, J. (eds.), Migration and the international labor market, 1850-1939. London and New York, Routledge.

----. 1995. Peopling the Pampa: On the economic impact of mass migration to the River Plate: 1870-1914. NBER Working Paper No. H0068. Cambridge MA. 
Timmer, A. and Williamson, J. 1996. Racism, xenophobia or markets? The political economy of immigration policy prior to the thirties. NBER Working Paper No. 5867. Cambridge MA. 


\section{Tables}


Table 1: GDP per capita of selected countries (1820-2000, in 1990 Geary-Khamis Dollars).)

\begin{tabular}{|c|c|c|c|c|c|c|c|c|}
\hline & \multicolumn{4}{|c|}{ First wave of Globalization, } & \multicolumn{4}{|c|}{ Second wave of globalization, } \\
\hline & \multicolumn{3}{|c|}{ Age of mass migration } & \multicolumn{4}{|c|}{ Constrained migration } & \multirow[b]{2}{*}{2000} \\
\hline & 1820 & 1870 & 1913 & 1950 & 1973 & 1990 & 1998 & \\
\hline \multicolumn{9}{|l|}{ Europe } \\
\hline Italy & 1117 & 1499 & 2564 & 3502 & 10643 & 16320 & 17759 & 19223 \\
\hline Spain & 1063 & 1376 & 2255 & 2387 & 8739 & 12210 & 14227 & 17392 \\
\hline Portugal & 963 & 997 & 1244 & 2069 & 7343 & 10852 & 12929 & 15296 \\
\hline Norway & 1104 & 1432 & 2501 & 5463 & 11246 & 18470 & 23660 & 29523 \\
\hline Sweden & 1198 & 1664 & 3096 & 6738 & 13493 & 17680 & 18685 & 20532 \\
\hline Average & 1089 & 1394 & 2332 & 4032 & 10293 & 15106 & 17452 & 20393 \\
\hline
\end{tabular}

Latin America

\begin{tabular}{|c|c|c|c|c|c|c|c|}
\hline Argentina & & 1311 & 3797 & 4987 & 7973 & 6512 & 9219 \\
\hline Brasil & 646 & 713 & 811 & 1672 & 3882 & 4924 & 5459 \\
\hline Chile & & & 2653 & 3821 & 5093 & 6401 & 9756 \\
\hline Colombia & & & 1236 & 2153 & 3499 & 4822 & 5317 \\
\hline Mexico & 759 & 674 & 1732 & 2365 & 4845 & 6097 & 6655 \\
\hline Peru & & & 1037 & 2263 & 3952 & 2955 & 3666 \\
\hline Uruguay & & 2005 & 3309 & 4660 & 4975 & 6473 & 8314 \\
\hline Venezuela & & 569 & 1104 & 7462 & 10625 & 8313 & 8965 \\
\hline Average & 703 & 1054 & 1960 & 3673 & 5606 & 5812 & 7169 \\
\hline
\end{tabular}

Other OECD countries

$\begin{array}{lcccccccc}\text { Australia } & 517 & 3645 & 5715 & 7493 & 12759 & 17043 & 20390 & 22462 \\ \text { Canada } & 893 & 1695 & 4447 & 7437 & 13838 & 18933 & 20559 & 23683 \\ \text { New Zealand } & 400 & 2704 & 5152 & 8453 & 12513 & 13825 & 14779 & 16068 \\ \text { United } & & & & & & & & \\ \text { States } & 1257 & 2445 & 5301 & 9561 & 16689 & 23214 & 27331 & 29513 \\ \text { Average } & \mathbf{7 6 7} & \mathbf{2 6 2 2} & \mathbf{5 1 5 4} & \mathbf{8 2 3 6} & \mathbf{1 3 9 5 0} & \mathbf{1 8 2 5 4} & \mathbf{2 0 7 6 5} & \mathbf{2 2 9 3 1}\end{array}$

Note: in 1990 Geary-Khamis Dollars -values in monetary units of each country converted into dollars at the purchasing power parity rates by Geary and Khamis expressed in 1990 US dollars

Source: Maddison (OECD) and International Financial Statistics (IMF). 
Table 2: Immigration to the United States, by region and selected country of last residence, fiscal years 1820-1998

\begin{tabular}{|c|c|c|c|c|c|c|c|c|c|c|c|c|c|c|c|}
\hline $\begin{array}{l}\text { Region / Country of last } \\
\text { residence }\end{array}$ & $1820-1870^{*}$ & $1871-80$ & $1881-90$ & $1891-1900$ & $1901-10$ & $1911-20$ & $1921-30$ & $1931-40$ & $1941-50$ & $1951-60$ & $1961-70$ & $1971-80$ & $1981-90$ & $1991-98$ & $\begin{array}{l}\text { Tot. } 179 \text { yrs } \\
1820-1998^{* *}\end{array}$ \\
\hline $\begin{array}{l}\text { Immigrants from all } \\
\text { countries }\end{array}$ & 7'377'238 & 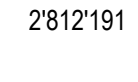 & $5^{\prime} 2466^{\prime} 613$ & $3^{\prime} 687^{\prime} 564$ & $8^{\prime} 795^{\prime} 386$ & $5^{\prime} 735 ' 811$ & 4'107'209 & $528^{\prime} 431$ & 1'035'039 & $2^{\prime} 515^{\prime} 479$ & 3'321'677 & 4'493'314 & 7'338'062 & $7^{\prime} 605 ' 068$ & $64^{\prime} 599^{\prime} 082$ \\
\hline $\begin{array}{l}\text { US population (mid- } \\
\text { decade) }\end{array}$ & $23^{\prime} 352^{\prime} 000$ & $45^{\prime} 245^{\prime} 000$ & $56^{\prime} 879^{\prime} 000$ & $69^{\prime} 851^{\prime} 000$ & $84^{\prime} 147^{\prime} 000$ & $100^{\prime} 941^{\prime} 000$ & $116^{\prime} 284^{\prime} 000$ & $127^{\prime} 859^{\prime} 000$ & $140^{\prime} 474^{\prime} 000$ & $165^{\prime} 931^{\prime} 000$ & $194^{\prime} 303^{\prime} 000$ & $215^{\prime} 973^{\prime} 000$ & $239^{\prime} 279^{\prime} 000$ & $263^{\prime} 044^{\prime} 000$ & $270^{\prime} 561^{\prime} 000$ \\
\hline Total immigrants / US pop. & $31.6 \%$ & $6.2 \%$ & $9.2 \%$ & $5.3 \%$ & $10.5 \%$ & $5.7 \%$ & $3.5 \%$ & $0.40 \%$ & $0.70 \%$ & $1.50 \%$ & $1.70 \%$ & $2.10 \%$ & $3.10 \%$ & $2.90 \%$ & $23.90 \%$ \\
\hline Europe & $6^{\prime} 717^{\prime} 328$ & 2'271'925 & $4^{\prime} 735^{\prime} 484$ & $3^{\prime} 555^{\prime} 352$ & $8^{\prime} 056^{\prime} 040$ & $4^{\prime} 321 ' 887$ & 2'463'194 & $347^{\prime} 566$ & $621 ' 147$ & $1 ' 325^{\prime} 727$ & $1 ' 123 ' 492$ & $800^{\prime} 368$ & $761 ' 550$ & $1 ' 132 ' 002$ & $38^{\prime} 233^{\prime} 062$ \\
\hline Austria (a) & $7^{\prime} 124$ & $63^{\prime} 009$ & $226^{\prime} 038$ & $234^{\prime} 081$ & $668 ' 209$ & $4533^{\prime} 649$ & $32 ' 868$ & 3'563 & $24^{\prime} 860$ & $67^{\prime} 106$ & $20^{\prime} 621$ & $9^{\prime} 478$ & $18^{\prime} 340$ & $13^{\prime} 776$ & $1^{\prime} 842 ' 722$ \\
\hline France & $244^{\prime} 049$ & $72 ' 206$ & $50^{\prime} 464$ & $30^{\prime} 770$ & $73^{\prime} 379$ & $61 ' 897$ & $49^{\prime} 610$ & $12^{\prime} 623$ & $38^{\prime} 809$ & $51^{\prime} 121$ & $45^{\prime} 237$ & $25^{\prime} 069$ & $32 ' 353$ & $29^{\prime} 063$ & $816^{\prime} 650$ \\
\hline Germany (b) & 2'333'944 & $718^{\prime} 182$ & 1'452'970 & $505^{\prime} 152$ & $341^{\prime} 498$ & $143^{\prime} 945$ & $412 ' 202$ & $114^{\prime} 058$ & $226 ' 578$ & $477 ' 765$ & $190^{\prime} 796$ & $74^{\prime} 414$ & $91 ' 961$ & $72 ' 792$ & 7'156'257 \\
\hline Hungary & 484 & $9^{\prime} 960$ & $127^{\prime} 681$ & $181 ' 288$ & $808 ' 511$ & $442^{\prime} 693$ & $30^{\prime} 680$ & $7^{\prime} 861$ & $3^{\prime} 469$ & $36^{\prime} 637$ & $5^{\prime} 401$ & $6^{\prime} 550$ & $6^{\prime} 545$ & $7^{\prime} 564$ & $1^{\prime} 675^{\prime} 324$ \\
\hline Ireland (c) & 2'392'335 & $4366^{\prime} 871$ & $655^{\prime} 482$ & $388^{\prime} 416$ & $339^{\prime} 065$ & $1466^{\prime} 181$ & $211^{\prime} 234$ & $10^{\prime} 973$ & $19^{\prime} 789$ & $48^{\prime} 362$ & $32^{\prime} 966$ & $11^{\prime} 490$ & $31 ' 969$ & $54 ' 865$ & 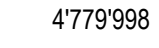 \\
\hline Italy & $25^{\prime} 518$ & $55^{\prime} 759$ & $307 ' 309$ & $651 ' 893$ & $2^{\prime} 045^{\prime} 877$ & 1'109'524 & $455 ' 315$ & $68^{\prime} 028$ & $57^{\prime} 661$ & $185^{\prime} 491$ & $214 ' 111$ & $129^{\prime} 368$ & $67^{\prime} 254$ & $58 ' 346$ & $5^{\prime} 431^{\prime} 454$ \\
\hline Soviet Union (d) & 3'886 & $39^{\prime} 284$ & $213^{\prime} 282$ & $505 ' 290$ & $1^{\prime} 597^{\prime} 306$ & 921'201 & $61^{\prime} 742$ & $1 ' 370$ & 571 & 671 & $2 ' 465$ & $38^{\prime} 961$ & $57 ' 677$ & $386^{\prime} 327$ & $3^{\prime} 830^{\prime} 033$ \\
\hline Sweden & na & $115^{\prime} 922$ & $391^{\prime} 776$ & $226 ' 266$ & $249^{\prime} 534$ & $95 ' 074$ & $97 ' 249$ & $3^{\prime} 960$ & $10^{\prime} 665$ & $21 ' 697$ & $17^{\prime} 116$ & $6^{\prime} 531$ & $11^{\prime} 018$ & $10^{\prime} 325$ & $1^{\prime} 257^{\prime} 133$ \\
\hline United Kingdom (e) & 1'401'213 & $548^{\prime} 043$ & $807 ' 357$ & $271^{\prime} 538$ & $525 ' 950$ & $341^{\prime} 408$ & $339 ' 570$ & $31^{\prime} 572$ & $1399^{\prime} 306$ & $202 ' 824$ & $213^{\prime} 822$ & $137 ' 374$ & $159^{\prime} 173$ & $128^{\prime} 671$ & $5^{\prime} 247^{\prime} 821$ \\
\hline Asia & $106 ' 529$ & $124^{\prime} 160$ & $69^{\prime} 942$ & $74 ' 862$ & $323^{\prime} 543$ & $247^{\prime} 236$ & $112^{\prime} 059$ & $16^{\prime} 595$ & $37^{\prime} 028$ & $153^{\prime} 249$ & $427^{\prime} 642$ & 1'588'178 & 2'738'157 & 2'346'751 & $8^{\prime} 365^{\prime} 931$ \\
\hline China (f) & $105^{\prime} 744$ & $123 ' 201$ & $61 ' 711$ & $14 ' 799$ & $20^{\prime} 605$ & $21^{\prime} 278$ & $29^{\prime} 907$ & $4^{\prime} 928$ & $16^{\prime} 709$ & 9'657 & $34^{\prime} 764$ & $124^{\prime} 326$ & $346^{\prime} 747$ & $347^{\prime} 674$ & $1^{\prime} 262^{\prime} 050$ \\
\hline Hong Kong (g) & na & na & na & na & na & na & na & na & na & $15^{\prime} 541$ & $75^{\prime} 007$ & $113^{\prime} 467$ & $98^{\prime} 215$ & $966^{\prime} 047$ & $398^{\prime} 277$ \\
\hline India & 196 & 163 & 269 & 68 & $4^{\prime} 713$ & $2 ' 082$ & 1'886 & 496 & $1 ' 761$ & $1^{\prime} 973$ & $27 ' 189$ & $164 ' 134$ & $250^{\prime} 786$ & $295^{\prime} 633$ & $751 ' 349$ \\
\hline Japan & 186 & 149 & $2^{\prime} 270$ & $25^{\prime} 942$ & $129^{\prime} 797$ & $83^{\prime} 837$ & $33^{\prime} 462$ & $1^{\prime} 948$ & 1'555 & $46 ' 250$ & $39 ' 988$ & $49^{\prime} 775$ & $47^{\prime} 085$ & $55^{\prime} 442$ & $517^{\prime} 686$ \\
\hline Korea (h) & na & na & na & na & na & na & na & na & 107 & $6^{\prime} 231$ & $34^{\prime} 526$ & $267^{\prime} 638$ & $333^{\prime} 746$ & $1366^{\prime} 651$ & 778'899 \\
\hline Philippines (i) & na & na & na & na & na & na & na & 528 & 4'691 & $19^{\prime} 307$ & $98 ' 376$ & $354^{\prime} 987$ & $548^{\prime} 764$ & $433^{\prime} 768$ & $1^{\prime} 460^{\prime} 421$ \\
\hline
\end{tabular}




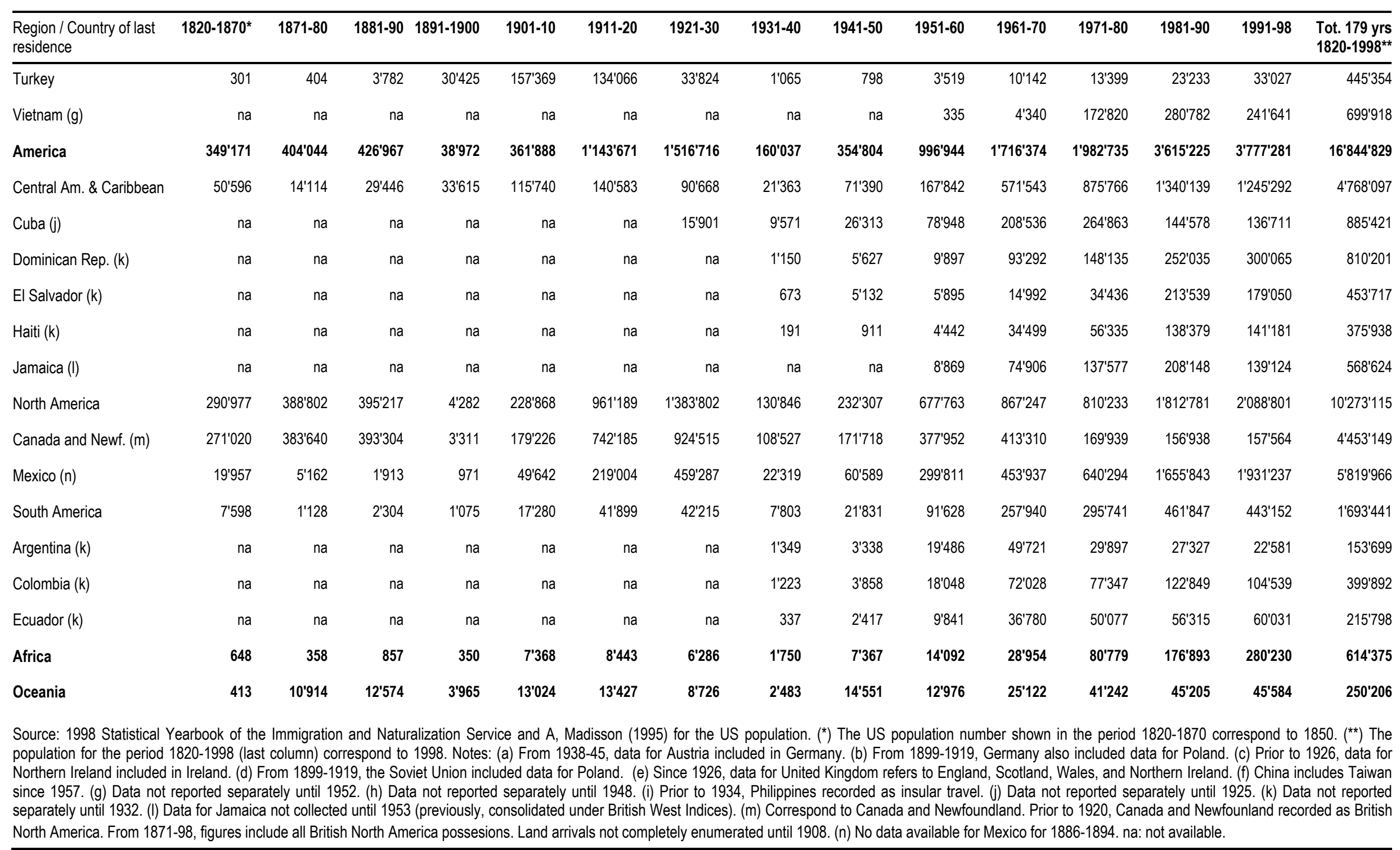


Table 3: Countries of Latin America: Level of per capita GDP, Period 1950-2000

\begin{tabular}{|c|c|c|c|c|c|c|c|c|c|c|c|c|c|}
\hline \multirow{3}{*}{$\begin{array}{l}\text { Years } \\
\\
1950- \\
1954\end{array}$} & \multicolumn{13}{|c|}{ Countries } \\
\hline & \multicolumn{5}{|c|}{ Argentina Bolivia Chile Colombia Costa Rica } & \multirow{2}{*}{$\begin{array}{c}\begin{array}{c}\text { Dominican } \\
\text { Rep. }\end{array} \\
1139\end{array}$} & \multicolumn{3}{|c|}{ EcuadorHaiti Mexico } & \multirow{2}{*}{$\begin{array}{c}\text { Nicaragua P } \\
1816\end{array}$} & \multirow{2}{*}{$\begin{array}{c}\text { Paraguayf } \\
1533\end{array}$} & \multicolumn{2}{|c|}{ Peru Venezuela } \\
\hline & 4920 & 1912 & 3998 & 2230 & 2134 & & 1990 & 1066 & 2478 & & & 2459 & 7898 \\
\hline $\begin{array}{l}1955- \\
1959\end{array}$ & 5384 & 1673 & 4135 & 2404 & 2474 & 1292 & 2162 & 1053 & 2918 & 2052 & 1571 & 2754 & 9549 \\
\hline $\begin{array}{l}1960- \\
1964\end{array}$ & 5696 & 1669 & 4529 & 2581 & 2821 & 1409 & 2319 & 1003 & 3295 & 2245 & 1629 & 3261 & 9280 \\
\hline $\begin{array}{l}1965- \\
1969\end{array}$ & 6541 & 1972 & 5049 & 2815 & 3371 & 1390 & 2596 & 888 & 3939 & 2793 & 1765 & 3675 & 9990 \\
\hline $\begin{array}{l}1970- \\
1974\end{array}$ & 7760 & 2283 & 5318 & 3352 & 4102 & 1840 & 3027 & 984 & 4626 & 2942 & 1980 & 3935 & 10499 \\
\hline $\begin{array}{l}1975- \\
1979\end{array}$ & 8112 & 2628 & 4790 & 3873 & 4691 & 2208 & 3705 & 1124 & 5433 & 2988 & 2543 & 4133 & 10947 \\
\hline $\begin{array}{l}1980- \\
1984\end{array}$ & 7621 & 2393 & 5349 & 4233 & 4483 & 2413 & 3958 & 1224 & 6342 & 2167 & 3258 & 3971 & 9341 \\
\hline $\begin{array}{l}1985- \\
1989\end{array}$ & 7058 & 2098 & 5682 & 4540 & 4524 & 2436 & 3874 & 1099 & 5926 & 1758 & 3147 & 3695 & 8645 \\
\hline $\begin{array}{l}1990- \\
1994\end{array}$ & 7515 & 2264 & 7255 & 4953 & 4962 & 2566 & 4000 & 913 & 6295 & 1400 & 3270 & 3009 & 8881 \\
\hline $\begin{array}{l}1995- \\
2000\end{array}$ & 8670 & 2405 & 9436 & 5262 & 5348 & 3124 & 4006 & 809 & 6550 & 1451 & 3182 & 3623 & 8752 \\
\hline $\begin{array}{l}1950- \\
2000\end{array}$ & 6962 & 2135 & 5630 & 3656 & 3920 & 2004 & 3180 & 1012 & 4815 & 2147 & 2403 & 3455 & 9366 \\
\hline $\begin{array}{l}\text { Note: } 19 \\
\text { Source: }\end{array}$ & $\begin{array}{l}\text { Geary-Kh } \\
\text { ddison (O }\end{array}$ & $\begin{array}{l}\text { is dolla } \\
\text { D) and }\end{array}$ & $\begin{array}{l}\text { ars. } \\
\text { Internat }\end{array}$ & Ial Fina & Statistics ( & F). & & & & & & & \\
\hline
\end{tabular}


Table 4: ratio of per capita GDP of recipient countries to sending countries*, selected Latin America and Caribbean countries

\begin{tabular}{|c|c|c|c|c|c|c|c|c|}
\hline \multirow{2}{*}{$\begin{array}{l}\text { Recipient } \\
\text { country: } \\
\text { Sending } \\
\text { country: }\end{array}$} & \multicolumn{3}{|c|}{ Argentina } & \multicolumn{2}{|c|}{ Chile } & \multirow{2}{*}{$\begin{array}{l}\text { Venezuela } \\
\text { Colombia }\end{array}$} & \multirow{2}{*}{$\begin{array}{l}\text { Costa Rica } \\
\text { Nicaragua }\end{array}$} & \multirow{2}{*}{$\begin{array}{c}\text { Dominican Rep } \\
\text { Haiti }\end{array}$} \\
\hline & Bolivia & Chile & Paraguay & Peru & Ecuador & & & \\
\hline $1950-1954$ & 2.58 & 1.23 & 3.21 & 1.63 & 2.01 & 3.54 & 1.18 & 1.07 \\
\hline $1955-1959$ & 3.23 & 1.30 & 3.43 & 1.50 & 1.91 & 3.97 & 1.21 & 1.23 \\
\hline $1960-1964$ & 3.42 & 1.26 & 3.50 & 1.39 & 1.95 & 3.60 & 1.26 & 1.41 \\
\hline $1965-1969$ & 3.32 & 1.30 & 3.71 & 1.37 & 1.94 & 3.55 & 1.21 & 1.57 \\
\hline $1970-1974$ & 3.40 & 1.46 & 3.92 & 1.35 & 1.77 & 3.14 & 1.39 & 1.87 \\
\hline $1975-1979$ & 3.09 & 1.71 & 3.22 & 1.16 & 1.29 & 2.83 & 1.62 & 1.97 \\
\hline $1980-1984$ & 3.19 & 1.43 & 2.34 & 1.35 & 1.35 & 2.21 & 2.07 & 1.97 \\
\hline $1985-1989$ & 3.37 & 1.25 & 2.25 & 1.56 & 1.47 & 1.91 & 2.61 & 2.22 \\
\hline $1990-1994$ & 3.31 & 1.04 & 2.30 & 2.41 & 1.81 & 1.79 & 3.55 & 2.86 \\
\hline $1995-2000$ & 3.60 & 0.92 & 2.73 & 2.60 & 2.36 & 1.66 & 3.69 & 3.86 \\
\hline $1950-2000$ & 3.26 & 1.28 & 3.05 & 1.65 & 1.80 & 2.80 & 2.01 & 2.04 \\
\hline \multicolumn{9}{|c|}{ Note: * Ratio based in GDP per capita in 1990 Geary-Khamis Dollars. } \\
\hline \multicolumn{9}{|c|}{ Source: Maddison (OECD) and International Financial Statistics (IMF). } \\
\hline
\end{tabular}


Table 5: Foreign population residing in Latin American countries (census years).

\begin{tabular}{|c|c|c|c|c|c|c|c|c|c|c|c|c|c|c|c|c|c|}
\hline \multirow[b]{2}{*}{$\begin{array}{l}\text { Country of } \\
\text { residence }\end{array}$} & \multirow[b]{2}{*}{ Year } & \multirow[b]{2}{*}{$\begin{array}{l}\text { Total }^{*} \\
\text { populati } \\
\text { on }\end{array}$} & \multicolumn{2}{|c|}{$\begin{array}{l}\text { Total foreign born } \\
\text { population }\end{array}$} & \multicolumn{13}{|c|}{ Country of Birth } \\
\hline & & & $\begin{array}{c}\text { [a] } \\
\text { as } \% \text { of } \\
\text { total } \\
\text { population }\end{array}$ & $\begin{array}{l}{[b]} \\
\text { Level }\end{array}$ & Argentina & Bolivia & Chile & Colombia & $\begin{array}{l}\text { Costa } \\
\text { Rica }\end{array}$ & Ecuador & Haiti & Nicaragual & Paraguay & Peru & $\begin{array}{l}\text { Dominican } \\
\text { Republic }\end{array}$ & Venezuela & $\begin{array}{l}\text { Rest of } \\
\text { the world }\end{array}$ \\
\hline \multirow[t]{4}{*}{ Argentina } & 1960 & $20^{\prime} 010^{\prime} 539$ & 12.7 & $2^{\prime} 540 ' 226$ & & $88^{\prime} 830$ & $116^{\prime} 840$ & 1'138 & 209 & 617 & 30 & 53 & $153^{\prime} 844$ & $5^{\prime} 164$ & 76 & 991 & $2^{\prime} 172 ' 434$ \\
\hline & 1970 & $23^{\prime} 390^{\prime} 050$ & 9.4 & 2'193'330 & & 101'000 & $142^{\prime} 150$ & N.A. & N.A. & N.A. & N.A. & N.A. & $230^{\prime} 050$ & N.A. & N.A. & N.A. & 1'720'130 \\
\hline & 1980 & $27^{\prime} 947^{\prime} 446$ & 6.6 & 1'857'703 & & $115^{\prime} 616$ & $207 ' 176$ & $1 ' 864$ & N.A. & 771 & N.A. & N.A. & $259^{\prime} 449$ & $8^{\prime} 002$ & N.A. & $1^{\prime} 401$ & 1'263'424 \\
\hline & 1991 & $32^{\prime} 615^{\prime} 528$ & 4.9 & 1'605'871 & & $143^{\prime} 735$ & $218^{\prime} 217$ & $2 ' 638$ & 451 & 975 & 73 & 142 & $251^{\prime} 130$ & $15^{\prime} 977$ & 259 & 1'934 & $970 ' 340$ \\
\hline \multirow[t]{2}{*}{ Bolivia } & 1976 & $4^{\prime} 613^{\prime} 486$ & 1.3 & $58^{\prime} 070$ & $14^{\prime} 669$ & & 7'508 & 412 & 40 & 183 & 16 & 18 & 972 & $4^{\prime} 730$ & 12 & 144 & $29^{\prime} 366$ \\
\hline & 1992 & 6'420'792 & 0.9 & $59^{\prime} 807$ & $17^{\prime} 829$ & & $3^{\prime} 909$ & 529 & 83 & 243 & 5 & 54 & 955 & $5^{\prime} 805$ & 36 & 300 & $30 ' 059$ \\
\hline \multirow[t]{3}{*}{ Chile } & 1970 & 8'884'768 & 1.0 & $88^{\prime} 881$ & $13^{\prime} 270$ & $7^{\prime} 563$ & & 800 & 101 & 967 & 52 & 56 & 290 & $3^{\prime} 804$ & 80 & 388 & $61^{\prime} 510$ \\
\hline & 1982 & $11^{\prime} 329^{\prime} 736$ & 0.7 & $84 ' 345$ & $19^{\prime} 733$ & $6^{\prime} 298$ & & $1^{\prime} 069$ & 191 & 1'215 & 36 & 99 & 284 & $4^{\prime} 308$ & 73 & 942 & $50^{\prime} 097$ \\
\hline & 1992 & $13^{\prime} 348^{\prime} 401$ & 0.9 & $114^{\prime} 597$ & $34^{\prime} 415$ & 7'729 & & $1^{\prime} 666$ & 448 & 2'267 & 37 & 168 & 683 & $7^{\prime} 649$ & 126 & 2'397 & $57^{\prime} 012$ \\
\hline \multirow[t]{3}{*}{ Colombia } & $1964^{*}$ & $17^{\prime} 484^{\prime} 508$ & 0.4 & $74^{\prime} 055$ & 1'190 & N.A. & 1'130 & & 400 & $10^{\prime} 126$ & N.A. & 272 & N.A. & $1^{\prime} 455$ & N.A. & $16^{\prime} 224$ & $43^{\prime} 258$ \\
\hline & $1985^{\star}$ & $27^{\prime} 837^{\prime} 932$ & N.A. & N.A. & N.A. & N.A. & N.A. & & N.A. & N.A. & N.A. & N.A. & N.A. & N.A. & N.A. & N.A. & N.A. \\
\hline & 1993 & $33^{\prime} 109^{\prime} 840$ & 0.3 & $106^{\prime} 162$ & 1'953 & 390 & $1^{\prime} 496$ & & 452 & $9^{\prime} 040$ & 64 & 307 & 137 & $3^{\prime} 182$ & 47 & $43^{\prime} 285$ & $45^{\prime} 809$ \\
\hline \multirow[t]{3}{*}{ Costa Rica } & 1963 & 1'336'274 & 2.6 & $34 ' 981$ & 144 & N.A. & 89 & 658 & & 135 & N.A. & $18^{\prime} 368$ & N.A. & N.A. & N.A. & 320 & $15^{\prime} 267$ \\
\hline & 1973 & 1'871'780 & 2.5 & $46^{\prime} 077$ & 347 & 87 & 670 & $1^{\prime} 014$ & & 272 & 25 & $23^{\prime} 331$ & 31 & 315 & 55 & 435 & $19^{\prime} 495$ \\
\hline & 1984 & $2^{\prime} 416^{\prime} 809$ & 3.7 & $88^{\prime} 954$ & 697 & 189 & $1^{\prime} 277$ & $1^{\prime} 678$ & & 318 & 30 & $45^{\prime} 918$ & 39 & $1^{\prime} 016$ & 134 & 748 & $36^{\prime} 910$ \\
\hline \multirow[t]{2}{*}{ Ecuador } & 1982 & $8^{\prime} 060^{\prime} 712$ & 0.9 & $75^{\prime} 404$ & $1^{\prime} 691$ & 381 & $5^{\prime} 747$ & $39^{\prime} 443$ & 280 & & 22 & 142 & 85 & $1^{\prime} 887$ & 102 & $1^{\prime} 674$ & $23^{\prime} 950$ \\
\hline & 1990 & 9'648'189 & 0.8 & 73'179 & $1^{\prime} 558$ & 424 & 4'948 & $37 ' 553$ & 313 & & 22 & 161 & 90 & 2'396 & 78 & 2'379 & $23 ' 257$ \\
\hline \multirow[t]{2}{*}{ Haiti } & 1971 & 4'329'991 & 0.1 & $6^{\prime} 000$ & 9 & 4 & 12 & 23 & 1 & 9 & & 8 & 2 & 10 & $1^{\prime} 659$ & 7 & $4^{\prime} 256$ \\
\hline & $1982^{*}$ & 5'053'189 & N.A. & N.A. & N.A. & N.A. & N.A. & N.A. & N.A. & N.A. & & N.A. & N.A. & N.A. & N.A. & N.A. & N.A. \\
\hline
\end{tabular}


Total foreign born

Country of Birth

population

\begin{tabular}{|c|c|c|c|c|c|c|c|c|c|c|c|c|c|c|c|c|c|}
\hline \multirow{2}{*}{$\begin{array}{l}\text { Country of } \\
\text { residence }\end{array}$} & \multirow{2}{*}{$\begin{array}{c}\text { Year } \\
1971\end{array}$} & \multirow{2}{*}{$\begin{array}{c}\begin{array}{c}\text { Total* } \\
\text { populati } \\
\text { on }\end{array} \\
1^{\prime} 877^{\prime} 952\end{array}$} & \multirow{2}{*}{$\begin{array}{c}\begin{array}{c}\text { [a] } \\
\text { as } \% \text { of } \\
\text { total } \\
\text { population }\end{array} \\
1.1\end{array}$} & \multirow{2}{*}{$\begin{array}{c}\begin{array}{c}{[b]} \\
\text { Level }\end{array} \\
21^{\prime} 174\end{array}$} & Argentina & Bolivia & \multirow{2}{*}{$\begin{array}{r}\text { Chile } \\
100\end{array}$} & \multicolumn{2}{|c|}{$\begin{array}{c}\text { Colombia Costa } \\
\text { Rica }\end{array}$} & \multicolumn{2}{|c|}{ Ecuador Haiti } & \multicolumn{3}{|c|}{ Nicaragua ParaguayPeru } & \multicolumn{3}{|c|}{$\begin{array}{l}\text { Dominican Venezuela Rest of } \\
\text { Republic } \quad \text { the world }\end{array}$} \\
\hline & & & & & 107 & N.A. & & 304 & $4^{\prime} 693$ & N.A. & N.A. & & N.A. & N.A. & N.A. & 87 & $15^{\prime} 883$ \\
\hline & 1995 & 4'357'099 & 0.6 & $26^{\prime} 043$ & 147 & 38 & 115 & 237 & $4^{\prime} 727$ & 78 & 20 & & 10 & 176 & 52 & 116 & $20^{\prime} 327$ \\
\hline \multirow[t]{3}{*}{ Paraguay } & 1972 & 2'357'955 & 3.4 & $79^{\prime} 686$ & $27^{\prime} 389$ & 364 & 359 & N.A. & N.A. & N.A. & N.A. & N.A. & & N.A. & N.A. & N.A. & $51^{\prime} 574$ \\
\hline & 1982 & $3^{\prime} 029^{\prime} 830$ & 5.5 & $1666^{\prime} 879$ & $43^{\prime} 336$ & 500 & $1^{\prime} 715$ & N.A. & N.A. & N.A. & N.A. & N.A. & & N.A. & N.A. & N.A. & $121^{\prime} 328$ \\
\hline & 1992 & 4'152'588 & 4.5 & $187^{\prime} 372$ & $47^{\prime} 846$ & 766 & $2^{\prime} 264$ & 189 & 45 & 72 & 13 & 24 & & $1^{\prime} 432$ & 14 & 91 & $134^{\prime} 616$ \\
\hline \multirow[t]{3}{*}{ Peru } & $1972^{*}$ & $13^{\prime} 538^{\prime} 208$ & 0.5 & $67 ' 186$ & 4'286 & 4'115 & $7^{\prime} 525$ & $1^{\prime} 528$ & $\ldots$ & 2'399 & N.A. & N.A. & N.A. & & N.A. & N.A. & $47^{\prime} 333$ \\
\hline & 1981 & $17^{\prime} 005^{\prime} 210$ & 0.4 & $66^{\prime} 925$ & $5^{\prime} 025$ & $3^{\prime} 210$ & $5^{\prime} 976$ & 1'985 & 190 & $1 ' 739$ & N.A. & N.A. & N.A. & & N.A. & 812 & $47^{\prime} 988$ \\
\hline & 1993 & $22^{\prime} 048^{\prime} 356$ & 0.2 & $52^{\prime} 725$ & 4'165 & $3^{\prime} 216$ & $4^{\prime} 652$ & $2^{\prime} 374$ & 215 & $1^{\prime} 801$ & 15 & 135 & 194 & & 104 & $1^{\prime} 489$ & $34^{\prime} 365$ \\
\hline Dominican & 1970 & $4^{\prime} 009^{\prime} 458$ & 0.8 & $32 ' 419$ & 213 & 21 & 47 & 120 & 40 & 57 & $19^{\prime} 065$ & 15 & 4 & 345 & & 114 & $12^{\prime} 378$ \\
\hline \multirow[t]{2}{*}{ Republic } & $1981^{*}$ & $5^{\prime} 545^{\prime} 741$ & N.A. & N.A. & N.A. & N.A. & N.A. & N.A. & N.A. & N.A. & N.A. & N.A. & N.A. & N.A. & & N.A. & N.A. \\
\hline & $1993^{*}$ & $7^{\prime} 293^{\prime} 390$ & N.A. & N.A. & N.A. & N.A. & N.A. & N.A. & N.A. & N.A. & N.A. & N.A. & N.A. & N.A. & & N.A. & N.A. \\
\hline \multirow[t]{3}{*}{ Venezuela } & 1971 & $10^{\prime} 721^{\prime} 522$ & 5.4 & $582 ' 560$ & $4^{\prime} 481$ & 1'166 & 2'999 & $177^{\prime} 973$ & 1'314 & $5^{\prime} 292$ & 353 & 866 & 186 & $2^{\prime} 168$ & 1'886 & & $383^{\prime} 876$ \\
\hline & 1981 & $14^{\prime} 516^{\prime} 735$ & 7.2 & 1'048'159 & $11^{\prime} 371$ & $2^{\prime} 301$ & $24^{\prime} 703$ & $494^{\prime} 494$ & $1 ' 795$ & $21^{\prime} 091$ & $1^{\prime} 238$ & $2^{\prime} 187$ & 456 & $19^{\prime} 956$ & $15^{\prime} 745$ & & $452^{\prime} 822$ \\
\hline & 1990 & $18^{\prime} 105^{\prime} 265$ & 5.7 & 1'024'121 & $9^{\prime} 070$ & $1 ' 936$ & $20^{\prime} 787$ & $528^{\prime} 893$ & $1 ' 494$ & $23^{\prime} 370$ & $1^{\prime} 593$ & $2^{\prime} 033$ & 494 & $27^{\prime} 748$ & $17^{\prime} 140$ & & $389^{\prime} 563$ \\
\hline
\end{tabular}

Source: Data base IMILA-International Migration in Latin America (ECLAC).

Notes: N.A. : Information not available in CELADE * Figures from census publications 
Table 6: Origins of Argentine immigration (five-year totals in thousands per person).

\begin{tabular}{lcccc}
\hline Origin & $1945-49$ & $1950-54$ & $1955-59$ & $1960-64$ \\
\hline Italians and Spaniards & & & & \\
\hline
\end{tabular}

Neighboring Countries

\begin{tabular}{|c|c|c|c|c|}
\hline Paraguayans & 16.1 & 41.1 & 104.2 & 87.1 \\
\hline Bolivians & 1.0 & 6.6 & 31.9 & 62.6 \\
\hline Chileans & 8.3 & 23.5 & 9.6 & 39.0 \\
\hline Brazilians & 4.7 & 9.5 & 1.4 & 6.7 \\
\hline Uruguayans & -33.8 & 9.0 & 19.3 & 6.0 \\
\hline (Sub-totals) & -3.7 & 89.7 & 166.4 & 201.4 \\
\hline Other Countries & 76.3 & 52.8 & 10.1 & 13.0 \\
\hline Totals & 329.0 & 418.4 & 250.4 & 218.3 \\
\hline
\end{tabular}


ธิ Table 7 : Argentina - Economic periods and international migration, 1870-2000.

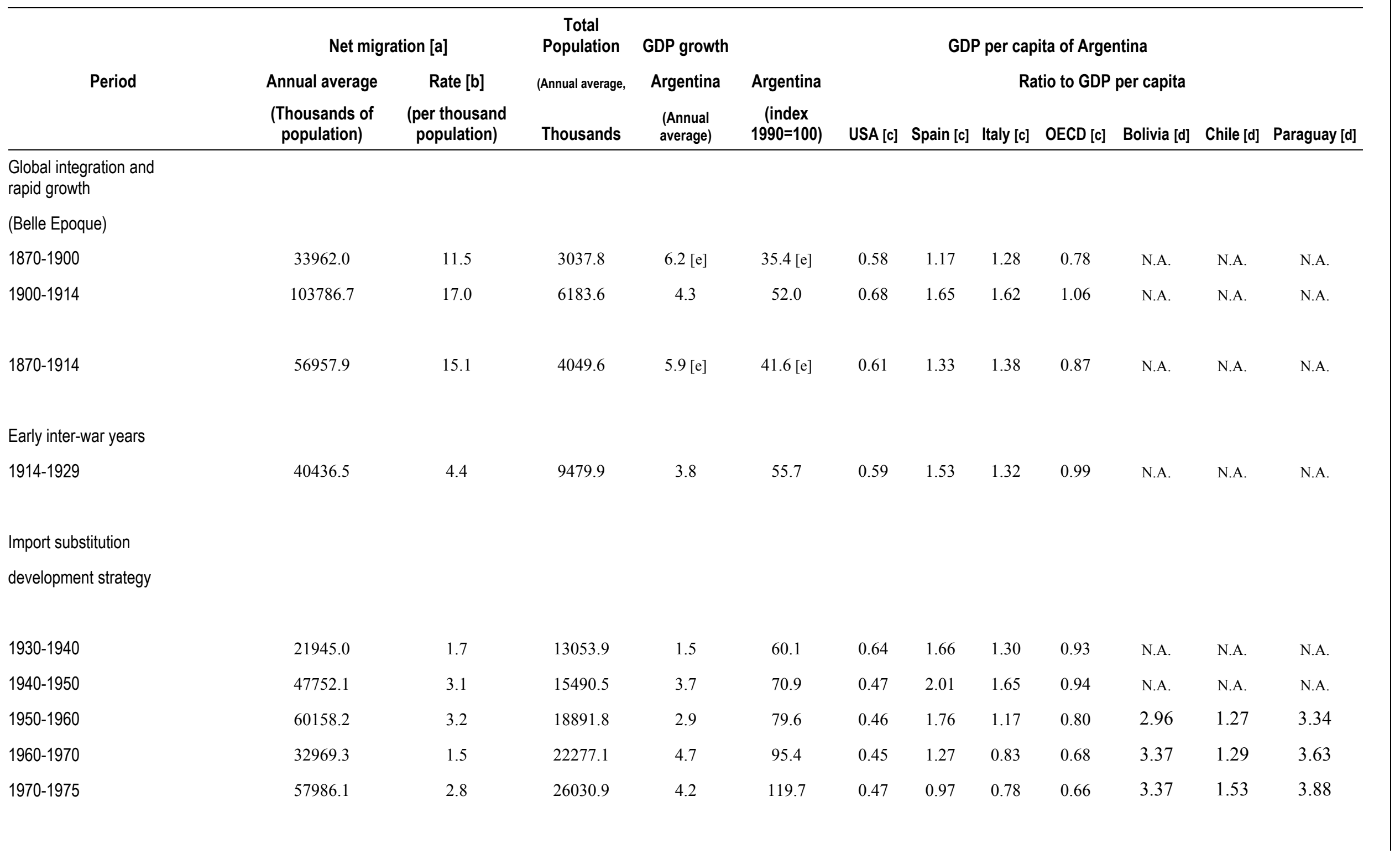




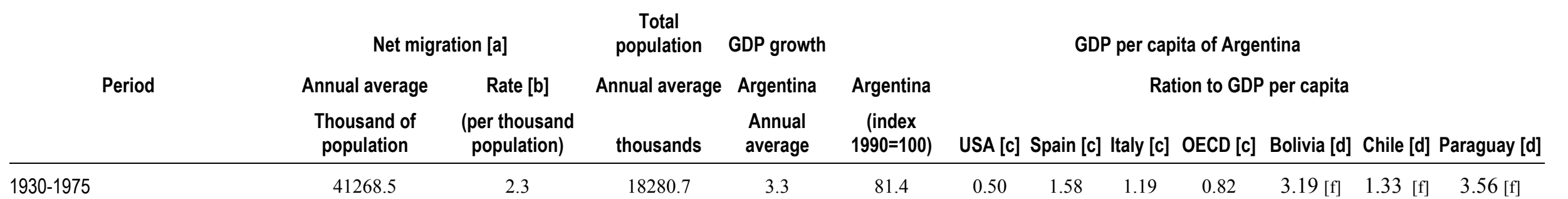

Early economic liberalization

1975-1990

$-1387.5$

29244.75

0.1

115.6

0.38

0.78

0.58

0.52

3.21

1.43

Intense economic reform and

liberalization

1990-2000

$-2155.3$

$-0.1$

34732.1

3.6

122.2

0.32

0.62

0.48

0.44

3.47

0.97

1975-2000

$-1683$

$-0.05$

31439.35

119.0

0.36

0.72

1870-2000 (average)

9685

6.4

18503.3

3.9 [e]

44.5 [e]

0.50

1.37

0.55

0.49

$\begin{array}{lll}3.33 & 1.25 & 2.57\end{array}$

Source: Andrés Solimano (2002),"Development Cycles, Political Regimes and International Migration: Argentina in the 20th Century". Paper presented at WIDER conference, "Poverty, International Migration and Asylum", September 27-28, 2002, Helsinki.

Notes: N.A.: Non-Available. [a] Net migration = Immigration - emigration. [b] Net migration Average / population of middle year of period. [c] in 1990 Geary-Khamis Dollars. [d] in constant 1995 dollars. [e] Since 1875. [f] Since 1950

Source: Argentine Government's National Direction of Migration,1970 Census Argentina, Demographic Bulletin 69 (ECLAC), International Monetary Fund, Maddison (2001), Roberto Cortés (1994), Solberg (1978), Bunge and Garcia Mata (1969) and Ferenczi and Wilcox (1929) 
Table 8: Argentina - Dependent variable: Rate of net migration, per 1000 population, 1900-1929.

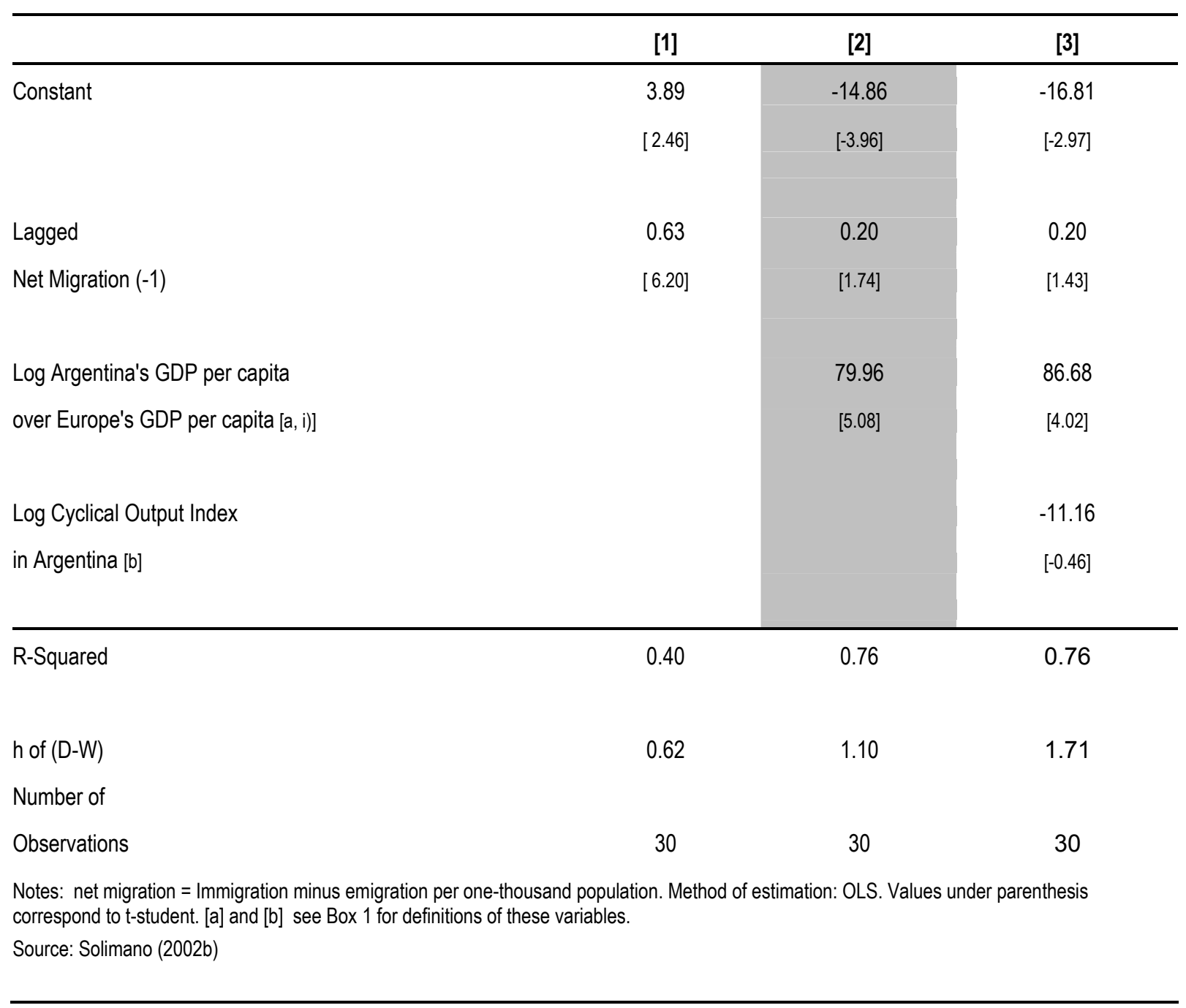


Table 9: Argentina - Dependent variable: Rate of net migration, per 1000 population, 1929-1960.

\begin{tabular}{|c|c|c|c|c|}
\hline & [1] & [2] & [3] & [4] \\
\hline \multirow[t]{2}{*}{ Constant } & 0.55 & 0.07 & 0.64 & 0.90 \\
\hline & [1.33] & {$[0.16]$} & [1.83] & [2.43] \\
\hline Lagged & 0.74 & 0.73 & 0.65 & 0.63 \\
\hline Net Migration (-1) & [6.91] & [7.50] & [8.31] & [8.23] \\
\hline Log Argentina's GDP per capita & & 5.58 & 2.74 & 2.97 \\
\hline over Europe's GDP per capita [a,ii)] & & [2.69] & [1.59] & [1.77] \\
\hline Log Cyclical Output Index & & & 22.86 & 21.32 \\
\hline in Argentina [b] & & & [4.51] & [4.27] \\
\hline Index of Political Regime [c] & & & & -0.75 \\
\hline R-Squared & 0.61 & 0.69 & 0.82 & 0.83 \\
\hline h of (D-W) & 2.91 & 2.48 & 1.32 & 1.18 \\
\hline \multicolumn{5}{|l|}{ Number of } \\
\hline Observations & 32 & 32 & 32 & 32 \\
\hline \multicolumn{5}{|c|}{$\begin{array}{l}\text { Notes: Rate of net migration = Immigration minus emigration per one-thousand population. Method of estimation: OLS. Values under parenthesis } \\
\text { correspond to t-student. [a], [b] and [c] see Box } 1 \text { for definitions these variables. } \\
\text { Source: Solimano (2002b) }\end{array}$} \\
\hline
\end{tabular}


Table 10: Argentina - Dependent variable: Rate of net migration, per 1000 population, 1960-1999.

\begin{tabular}{|c|c|c|c|c|c|c|}
\hline & [1] & [2] & [3] & [4] & {$[5]$} & {$[6]$} \\
\hline \multirow[t]{2}{*}{ Constant } & -20.51 & -21.15 & -25.31 & -40.52 & -58.85 & -56.08 \\
\hline & {$[-3.20]$} & {$[-3.44]$} & {$[-3.50]$} & {$[-4.98]$} & {$[-1.50]$} & {$[-1.36]$} \\
\hline Log Argentina's GDP per capita & 9.19 & 9.60 & 11.51 & 18.24 & 25.24 & 24.07 \\
\hline over GDP per capita neighborgh & [3.13] & {$[3.41]$} & {$[3.51]$} & {$[5.01]$} & {$[1.67]$} & {$[1.52]$} \\
\hline \multicolumn{7}{|l|}{ countries of Argentina [a] } \\
\hline Log Cyclical Output Index & & 27.46 & 27.51 & 34.12 & 41.68 & 41.27 \\
\hline in Argentina [b] & & {$[1.81]$} & {$[1.85]$} & {$[2.36]$} & {$[1.92]$} & {$[1.85]$} \\
\hline Lagged & & & -0.27 & -0.34 & -0.34 & -0.34 \\
\hline Net Migration (-1) & & & {$[-1.38]$} & {$[-1.83]$} & {$[-1.80]$} & {$[-1.76]$} \\
\hline Lagged & & & & -0.54 & -0.49 & 0.50 \\
\hline Net Migration (-2) & & & & {$[-2.79]$} & {$[-2.23]$} & {$[-2.20]$} \\
\hline Log Argentina's GDP per capita & & & & & -6.49 & -5.78 \\
\hline over Europe's GDP per capita [c] & & & & & {$[-0.47]$} & {$[-0.41]$} \\
\hline Index of Political Regime [d] & & & & & & 0.60 \\
\hline R-Squared & 0.29 & 0.37 & 0.43 & 0.64 & 0.64 & 0.64 \\
\hline$(\mathrm{D}-\mathrm{W})$ & 2.51 & 2.71 & $1.57[\mathrm{e}]$ & $(-1)[f]$ & $(-0.87)[f]$ & $0.40[\mathrm{f}]$ \\
\hline \multicolumn{7}{|l|}{ Number of } \\
\hline Observations & 32 & 32 & 30 & 28 & 28 & 28 \\
\hline
\end{tabular}

Notes: Rate of net migration = Immigration minus emigration per one-thousand population. Method of estimation: OLS. Values under parenthesis correspond to t-student. [a], [b], [c] and [d] see Box 1 for definitions of these variables.. [e] $h$ of Durbin - Watson. [f] t-student of lagged resid(-1) (resid ecuation with respect to your original ecuation + resid(-1))

Source: Solimano (2002b) 
Table 11: Argentina - Dependent variable: Rate of net migration, per 1000 population 1900-1999 (3 year average).

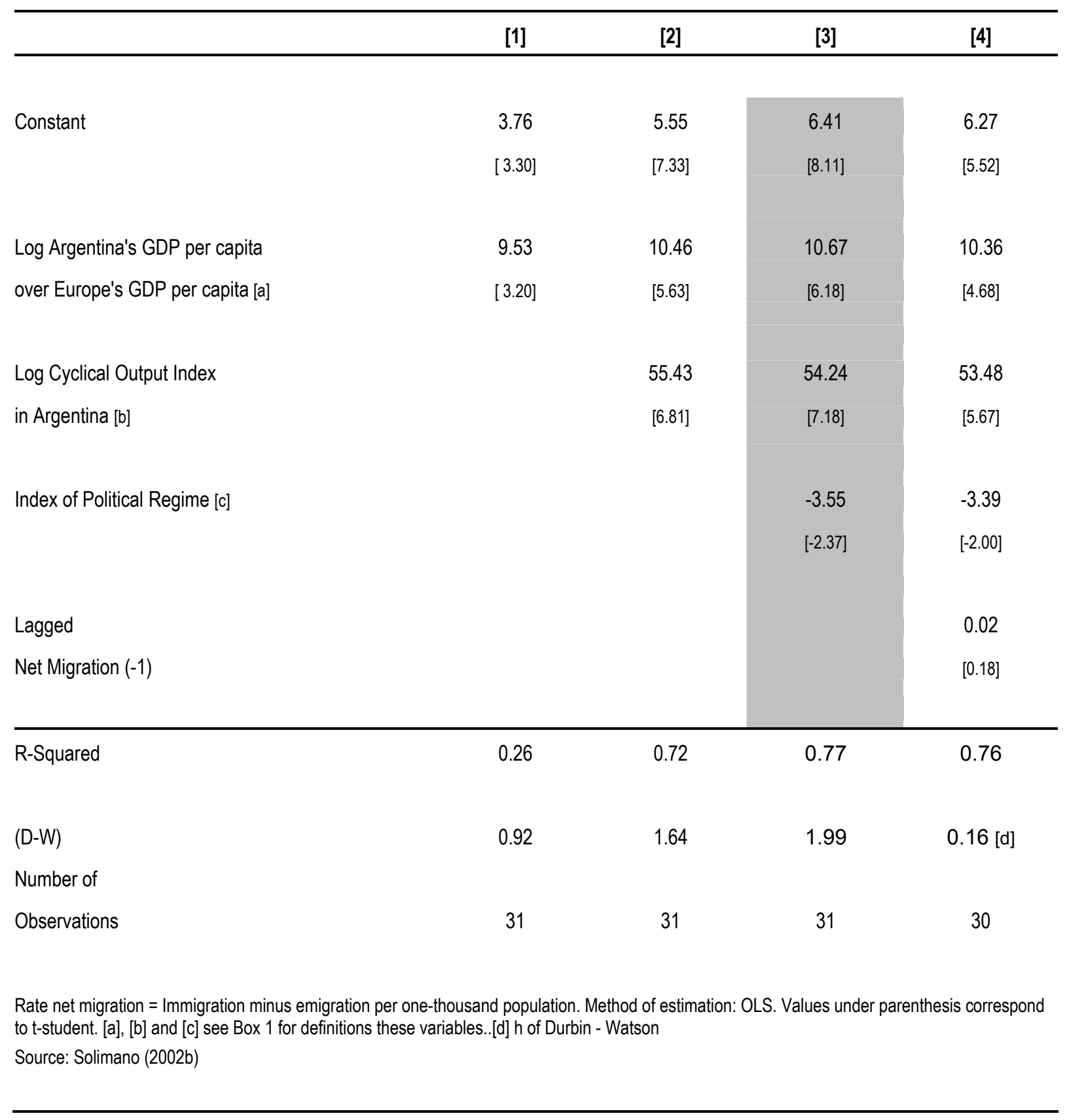




\section{Construction of variables}

- Rates of net migration: Immigration minus emigration per 1,000 population.

- Argentina's per capita GDP: GDP of Argentina in millions of international 1990 GearyKhamis dollars/Population of Argentina in 1,000s at mid-year.

- Europe's per capita GDP: per capita GDP is measured in millions of international 1990 Geary-Khamis dollars/Population in 1,000s at mid-year.

1. Europe's per capita GDP (1990-1929 = 1/3 (1/6 per capita of GDP of Austria + per capita GDP of Belgium + per capita GDP of France + per capita GDP of Germany + per capita GDP of Switzerland + per capita GDP of UK + per capita GDP of Spain + $1 / 3$ of per capita of Italy (the change in weights reflects the decline in importance of Italy and Spain as a source of immigration to Argentina).

2. Europe's per capita GDP $(1929-1960,1960-1999)=1 / 8$ (per capita GDP of Austria + per capita GDP of Belgium + per capita GDP of France + per capita GDP of Germany + per capita GDP of Switzerland + per capita GDP of UK + per capita GDP of Spain + per capita GDP of Italy).

- Per capita GDP of Argentina's neighboring countries: per capita GDP is measured in millions of 1995 dollars/Population in 1,000s at mid-year.

- Per capita GDP (1950-2000) of neighboring countries of Argentina = 1/3 (per capita GDP of Bolivia + per capita GDP of Chile + per capita GDP of Paraguay).

- Cyclical output index: Ratio of Argentina's GDP in millions in 1990 international GearyKhamis dollars divided by GDP trend of Argentina in millions of international 1990 GearyKhamis dollars.

- The GDP trend of Argentina was constructed using the Hodrick-Prescott filter.

- Index of political regime: Dummy variable with $1=$ Authoritarian and $0=$ Democratic. 


\section{Policy Integration Department Working Papers prepared for the World Commission on the Social Dimension of Globalization}

No. 16 International finance: Meeting the needs of people in developing countries, José Guilherme Almeida dos Reis

No. 17 The gender dimensions of globalisation of production, Stephanie Barrientos, Naila Kabeer and Naomi Hossain

No. 18 Social exclusion in the context of globalization, Jan Breman

No. 19 Gender and globalization: A macroeconomic perspective, Çağatay Nilüfer and Ertük Korkurt

No. 20 Globalization, social exclusion, and work: With special reference to informal employment and gender, Marilyn Carr and Martha Chen

No. 21 Resources for social development, Antony Clunies Ross

No. 22 Does the new international trade regime leave room for industrialization policies in the middle-income countries?, Alisa DiCaprio and Alice Amsden

No. 23 Social dimension of globalisation in Latin America: Lessons from Bolivia and Chile, Alvaro García Hurtado

No. 24 Globalization: Social impact and policy actions: A partly annotated bibliography, Bernhard Gunter and Rolph van der Hoeven

No. 25 The social dimension of global production systems, Susan Hayter

No. 26 Reforming global economic and social governance:

a critical review of recent programmatic thinking, Jeremy Heimans

No. 27 Corporate social responsibility: An issues paper, Michael Hopkins

No. 28 Upgrading in global value chains, John Humphrey

No. 29 Implications of globalization and economic restructuring for skills development in Sub-Sahara Africa, Richard K. Johanson

No. 30 The outcome and impact of the main international commissions on development issues, Frédéric Lapeyre

No. 31 Globalization and structural adjustment as a development tool, Frédéric Lapeyre

No. 32 Globalization and perceptions of social inequality, Malte Luebker

No. 33 The changing structure of trade linked to global production systems: what are the policy implications?, William Milberg

No. 34 Corporate social responsibility: An overview of principles and practice, Jill Murray

No. 35 Inclusive development strategy in an era of globalization, Ignacy Sachs

No. 36 Social consequences of the globalization of the media and communications sector: Some strategic considerations, Seán Ó. Siochrú

No. 37 Globalization, history and international migration - A view from Latin America, Andrés Solimano

No. 38 Towards a different kind of globalization, or how the anti-globalizers view the world, Gijsbert van Liemt 